ZAPISKi HistoryCZNE t. 85, 2020, z. 1, s. 91-122

ISSN 0044-1791

http://dx.doi.org/10.15762/ZH.2020.03

STANISEAW WITKOWSKI*

(iD) https://orcid.org/0000-0002-1468-0401

\title{
Geneza powolania Komitetu Polskiego w Sztokholmie W LATACH PIERWSZEJ WOJNY ŚWIATOWEJ
}

\author{
Abstract \\ The Origins of the Polish Committee in Stockholm \\ during the First World War
}

The aim of the article is to present the origins of the Polish Committee in Stockholm during the First World War. The author verifies all the findings that researchers in this field have made so far. Józefa Ledóchowska, an Ursuline nun, stated that the Polish Committee in Stockholm was established on the initiative of Aleksander Lednicki, President of the Council of Polish Organisation Congresses for War Victims and the Polish Committee in Moscow. Andrzej Nils Uggla presented a different view on the origins of the Stockholm Committee. He argued that the organization was established on the initiative of Polish emigration in Sweden, which originated from the descendants of emigrants who came to this country after the January Uprising, supported by national democrats. The above-mentioned researchers did not present the sources on which they based their findings. Based on primary sources stored in Swedish and Polish archives, as well as Swedish and Polish press, the author of the article confronted both aforementioned claims. A detailed analysis of the above-mentioned primary sources allowed to determine that the initiative to establish the Polish Committee in the Swedish capital was taken during the mission of Józef Evert, Vice-President of the Polish Committee in Moscow, who went to Stockholm. The mission took place at the end of November and beginning of December 1915. In Stockholm, Evert met the representatives of the 'old emigration', as well as the 'new emigration' caused by the First World War. The talks resulted in an offer made by Evert to allocate a certain amount of money from the funds of aid organizations operating in Russia to a charity to be established in Sweden. The goal of this new organisation was to help the Poles living in Sweden regardless of their citizenship.

Keywords: Poles in Sweden; charity initiatives; Polish Committee in Stockholm; Alf de Pomian; Ursula Ledóchowska; Józef Evert; First World War

\footnotetext{
* Niezależny badacz,

(@) nowina333@op.pl
}

Nadesłany 23.07.2018; Nadesłany po poprawkach 10.10.2019; zaakceptowany 15.05.2020 
Komitet Polski w Sztokholmie, nazywany także Polskim Komitetem Ratunkowym lub Polskim Komitetem Pośredniczącym, działający w latach 1916-1919, nie doczekał się opracowania na temat jego genezy i działalności. Nieliczni badacze piszący o Komitecie lub ci, którzy jedynie wspominają o nim na marginesie swoich podstawowych rozważań, odmiennie opisują początek procesu formowania się tej organizacji. Komitet Polski w Sztokholmie przeszedł krótką, ale burzliwą drogę. Powołaniu tej organizacji charytatywnej towarzyszyły nie do końca znane okoliczności. Spory orientacyjne w wyniku Manifestu 5 XI 1916 r. doprowadziły do dekompozycji Komitetu Polskiego w 1917r. Skutkiem następujących po sobie zdarzeń powstały dwie oddzielne organizacje: przejęty przez aktywistów Komitet Polski i Polskie Biuro Pomocy dla Jeńców ${ }^{1}$. W artykule tym koncentrujemy się wyłącznie na genezie powołania Komitetu Polskiego w Sztokholmie.

Nie jest możliwe przedstawienie w ramach jednego artykułu genezy i tworzenia tej nowej organizacji charytatywnej. W prezentowanym tekście skoncentrowaliśmy się zatem na sprawach nowych, nieznanych badaczom tej problematyki i z naszego punktu widzenia najistotniejszych, dotyczących konkretnego problemu, w tym przypadku genezy sztokholmskiego Komitetu Polskiego. Próbując wyjaśnić nieznane do tej pory kulisy jego powołania, dotarliśmy do źródeł archiwalnych w Szwecji, tekstów opublikowanych w prasie szwedzkiej i polskiej, zbiorów polskich archiwów, wspomnień osób, które były naocznymi świadkami tych wydarzeń, a także relacji spisanych i dotychczas niepublikowanych. Na przestrzeni kilkudziesięciu lat spisywaliśmy relacje ustne osób, które w chwili ich nagrywania były jeszcze wśród nas. Relacje te pozostają w posiadaniu autora artykułu. Wreszcie wykorzystano opracowania naukowe, które w mniejszym lub większym zakresie były pomocne w przygotowaniu tego tekstu. Zasadniczym celem było dotarcie do informacji dotyczących inspiratorów w sensie personalnym lub organizacji, które przyczyniły się do powołania Komitetu. Podjęte badania nie pozwoliły na wyjaśnienie wszystkich aspektów związanych z jego istnieniem. Próby dotarcia do archiwów rosyjskich zakończyły się niepowodzeniem, nad czym autor ubolewa. Pozwoliłyby one na wyjaśnienie kwestii, które musiały zostać przedstawione z poczuciem, że nie jest to kompletny opis niektórych procesów i wydarzeń. Mimo wszystko zgromadzony materiał wydaje się na tyle cenny i pełny, że pozwala przedstawić zasadnicze etapy i okoliczności genezy Komitetu Polskiego w Sztokholmie.

${ }^{1} \mathrm{Na}$ ich temat szczegółowo piszemy w przygotowywanym do publikacji opracowaniu „Polacy w Szwecji w latach 1903-1919”. 
Spośród polskich badaczy jako pierwsza do kwestii powołania Komitetu Polskiego w Sztokholmie nawiązała Józefa Ledóchowska² ze Zgromadzenia Urszulanek Serca Jezusa Konającego (USJK) w opublikowanej biografii Julii Urszuli Ledóchowskiej. W roli inicjatora powołania sztokholmskiego Komitetu Polskiego widziała Aleksandra Lednickiego, prezesa Rady Zjazdów Polskiej Organizacji Pomocy Ofiarom Wojny (RZPOPOW) i Komitetu Polskiego w Moskwie. Motywy powołania Komitetu przedstawiła następująco: „Kolonia polska w Sztokholmie była stosunkowo liczna, ale mało zorganizowana. Dopiero w kwietniu 1916, na wniosek Aleksandra Lednickiego, został utworzony Komitet Polski, który miał reprezentować polską rację stanu w krajach skandynawskich”3. Józefa Ledóchowska USJK nie przywołała źródła, z jakiego zaczerpnęła wiedzę o inspirującej roli A. Lednickiego w powołaniu tej nowej organizacji charytatywnej. Z dużym prawdopodobieństwem, graniczącym z pewnością, można przyjąć, że informację tę znalazła we wspomnieniach matki Urszuli Ledóchowskiej, spisanych w 1924 r. Memuary te, zatytułowane Historia Kongregacji Sióstr Urszulanek Najświętszego Serca Jezusa Konającego, zanim je opublikowano w 1987 r., przechowywano w postaci maszynopisu w Archiwum Głównym Urszulanek Serca Jezusa Konającego w Pniewach (AGUSJK w Pniewach) ${ }^{4}$.

${ }^{2}$ Józefa Maria-Immaculata Ernestyna Zofia Ledóchowska, s. Maria Józefa od Chrystusa Króla (6 XII 1907 - 15 VI 1983). Urodzona w Krakowie córka Ignacego Ledóchowskiego, generała dywizji Wojska Polskiego, brata Julii Ledóchowskiej i Pauliny z Łubieńskich. Więcej na temat jej życia i działalności zob. www.urszulanki.pl/index.php/indeks-litera-1/1303 -ledochowska-jozefa-maria-immaculata-ernestyna-zofia-s-m-jozefa-od-chrystusa-krola [dostęp z 15 V 2017 r.].

${ }^{3}$ Józefa Ledóchowska, Życie i działalność Julii Urszuli Ledóchowskiej, Poznań 1975, s. 148.

${ }^{4}$ Matka Urszula Ledóchowska rozpoczęła pisanie „historii naszej Kongregacji” w niedzielę, 8 VI 1924 r. (w dniu Zesłania Ducha Świętego), a zakończyła w pierwszej dekadzie października tegoż roku. W latach 1941-1944, na polecenie siostry przełożonej Stanisławy Prądzyńskiej, przebywająca w Czarnej pod Warszawą, gdzie mieścił się jeden z domów zgromadzenia, siostra Teresa Gregorowicz USJK sporządziła rękopiśmienną kopię tego dzieła. W czasie powstania warszawskiego rękopis matki Urszuli Ledóchowskiej zaginął. W 1950 r. na podstawie rękopiśmiennej kopii powstał maszynopis, który powielono w tym samym roku w Pniewach, zaznaczając, że jest to „odpis autentycznej kopii”. Powielony tekst posłużył za podstawę pierwszego wydania: Urszula LedóchowsKa, Historia Kongregacji Sióstr Urszulanek Najświętszego Serca Jezusa Konajacego, Poznań 1987. Zostało ono opublikowano przez poznańskie wydawnictwo księży pallotynów Pallottinum w nakładzie 20000 egzemplarzy. Tekst opracował zespół w składzie: s. Andrzeja Górska, s. Angelika Jakubiak, s. Ancilla Kosicka, s. Józefa Zdybicka. W 1992 r. wydawnictwo Belmont-Tramonet ogłosiło drukiem wydanie w języku francuskim: Ursule Ledóchowska, Histoire de la Congrégation des Ursulines S.J.A., Lyon 1992. Drugie polskie wydanie opublikowano równo 20 lat po jego pierwszej edycji pod zmienionym tytułem: Urszula LedóchowsKa, Byłam tylko pionkiem na szachownicy... Wspomnienia z lat 1886-1924, red. Małgorzata Krupecka, Ancilla KosickA, wstęp Małgorzata Krupecka, Częstochowa 2007. W artykule wykorzystano wydanie z 1987 r. Zob. U. LedóchowsKA, Historia Kongregacji Sióstr 
O kluczowej roli A. Lednickiego jako inicjatora w powołaniu sztokholmskiego Komitetu Polskiego pisał także Janusz Sibora. I chociaż nie przywołuje on opracowania J. Ledóchowskiej USJK, ani zresztą żadnego innego, to jednak wyraźnie widać, że właśnie u autorki biografii matki U. Ledóchowskiej znalazł dosłowną inspirację do następujących twierdzeń: „W kwietniu 1916 roku matka Urszula weszła w skład zarządu utworzonego z inicjatywy A. Lednickiego Komitetu Polskiego, który miał reprezentować polską rację stanu w krajach skandynawskich" ". W tym miejscu należy zaznaczyć, że informacja w przywołanym cytacie J. Sibory o tym, jakoby już w kwietniu 1916 r. matka U. Ledóchowska weszła w skład zarządu Komitetu, jest błędna. Nastąpiło to dopiero 6 X 1916 r. $^{6}$

Całkowicie odmienny pogląd w tej kwestii wyraził polsko-szwedzki literaturoznawca Andrzej Nils Uggla ${ }^{7}$. Genezę powstania Komitetu i jego inspiratorów przedstawił on w następujący sposób: „Komitet założony był przez starą emigrację w Szwecji, związaną z ugrupowaniami prorosyjskiej Narodowej Demokracji”. W innym miejscu stwierdził, że „Początkowo rolę polskiej placówki opiekuńczej sprawował, związany z Narodową Demokracją, tzw. Oddział Polski przy Rosyjskim Komitecie Pomocy. Ponieważ Polaków nadjeżdżało coraz więcej, [...] oddział ten przekształcił się w samodzielny Komitet Polski Ratunkowy, potocznie nazywany Komitetem Polskim"9. Co ciekawe,

Urszulanek, s. 4-11; eadem, Bytam tylko pionkiem na szachownicy, s. 3-14; Teresa BoJARSKA, W imię trzech krzyży. Opowieść o Julii Urszuli Ledóchowskiej i jej zgromadzeniu, Warszawa 1989, s. 64-75. Relacja s. Ancilli Kosickiej opowiadająca o losach rękopiśmiennej kopii wspomnień matki U. Ledóchowskiej, spisana w dniach 5 i 7 V 2011 r., znajduje się w posiadaniu autora artykułu.

${ }^{5}$ Janusz Sibora, Dyplomacja polska w I wojnie światowej, Warszawa 2013, s. 217; idem, Narodziny polskiej dyplomacji u progu niepodległości, Warszawa 1998, s. 97-98. W obu wymienionych publikacjach J. Sibory zawarta w tekście fraza dotycząca powołania Komitetu Polskiego w Sztokholmie brzmi identycznie.

${ }^{6}$ Pismo Stanisława Wędkiewicza do szefa biura sekretariatu Naczelnego Komitetu Narodowego w Krakowie dr. Jana Dąbrowskiego, Stockholm, Nybrogatan 6, 8 X [1916], Archiwum Narodowe w Krakowie, Naczelny Komitet Narodowy (dalej cyt. ANK, NKN), sygn. 50, k. 138-139.

${ }^{7}$ Spośród jego prac zostały wykorzystane: Andrzej N. UGGLA, Svensk-polska hjälpkommittéen i Sverige 1916-1918, Studia Scandinavica. Zeszyty Naukowe Uniwersytetu Gdańskiego, z. 14: 1996, s. 101-110. Jest to numer jubileuszowy zawierający materiały z konferencji zorganizowanej z okazji 25-lecia Katedry Skandynawistyki Uniwersytetu Gdańskiego. Artykuł ten siedem lat później został opublikowany w polskiej wersji językowej; zob. idem, Komitet Pomocy w Szwecji 1916-1918, Pamiętnik Literacki, nr 28: 2003, s. 8-24.

${ }^{8}$ A. N. UgGla, Komitet Pomocy, s. 11; idem, Svensk-polska hjälpkommittéen, s. 104. Pogląd ten spotykamy w innym artykule tego autora; zob. idem, Rola Alfa de Pomiana-Haydukiewicza w grze o wizerunek Polski $w$ Szwecji po pierwszej wojnie światowej, [in:] Polska-Szwecja 1919-1999, red. Jan Szymański, Gdańsk 2000, s. 79.

${ }^{9}$ A. N. UgGla, Komitet Pomocy, s. 9. 
i ten autor nie podał źródła, które skłoniło go do takiego sądu. Przypuszczalnie wykorzystał informację dotyczącą Komitetu zawartą w wydawanej w Moskwie przez narodowych demokratów „Gazecie Polskiej”. Czytamy tam, co następuje: „Oddział polski przy Rosyjskim Komitecie Pomocy przekształcił się na samodzielny i już zalegalizowany Komitet Polski Ratunkowy”10. Publikacja zawarta w „Gazecie Polskiej” była A. N. Uggli znana, przywołuje ją bowiem w innym miejscu przytoczonego artykułu. Szlakiem twierdzeń tego badacza podążyli w swoich opracowaniach: Adam Staniszewski ${ }^{11}$, Kazimierz T. Matuszak $^{12}$ i Janina J. Ćwirko-Godycka ${ }^{13}$. Żadna z tych osób nie starała się zweryfikować poglądów A. N. Uggli.

Jak wynika z powyższego zestawienia, wśród autorów piszących o genezie sztokholmskiego Komitetu Polskiego występują dwie odmienne opinie. Pierwsza z nich, reprezentowana przez J. Ledóchowską USJK, a także przez J. Siborę, przypisuje inspirację do stworzenia tej nowej organizacji ratunkowej ośrodkowi zewnętrznemu. Z kolei A. N. Uggla postrzega ją jako efekt wypływający $\mathrm{z}$ wewnętrznej potrzeby samych wychodźców. W tej sytuacji zmuszeni jesteśmy podjąć się próby weryfikacji głoszonych twierdzeń na temat genezy sztokholmskiego Komitetu Polskiego.

Komitet Polski w Sztokholmie dał się poznać opinii publicznej w trzeciej dekadzie marca 1916 r., gdy na łamach prasy szwedzkiej pojawiły się informacje dotyczące nowej organizacji charytatywnej o nazwie: Polski Komitet Pośredniczący (Polska förmedlingskommittéen) bądź Komitet Polski (Polska kommittéen). Nazwy te w prasie szwedzkiej stosowano zamiennie ${ }^{14}$.

Ważnym źródłem poznania genezy Komitetu Polskiego w Sztokholmie jest tekst datowany na 31 III 1916r. w stolicy Szwecji, który ukazał się w postaci anonsu 11, 12, 14 i 30 IV 1916 r. na łamach polskiej prasy codziennej w Galicji, zaborze pruskim i Rosji ${ }^{15}$. Pod tekstem widnieje podpis Alfa de Pomia-

${ }^{10}$ Komitet Polski w Sztokholmie, Gazeta Polska, 2/15 II 1916, nr 32, s. 1.

${ }^{11}$ Adam Staniszewski, Po dwóch stronach Baltyku. Polityczno-gospodarcze stosunki polsko-szwedzkie w latach 1918-1932, Toruń 2013, s. 57-59, przyp. 112. Autor powołuje się na maszynopis: Andrzej N. Uggla, Działalność Polskiego Komitetu Pomocy w Szwecji w momentach zagrożeń politycznych [s.l., s.a.].

${ }^{12}$ Kazimierz T. Matuszak, Polski Komitet Pomocy w Szwecji, [in:] Polacy w Szwecji po II wojnie światowej. Materiały sympozjum, luty 1989, Sztokholm 1992, s. 13.

${ }^{13}$ Janina J. ĆwIrko-GodyckA, Organizacje polonijne w Szwecji i ich działalność, Jonstorp 1996, s. 5.

${ }^{14}$ De polska flyktingarna i Sverge, Dagens Nyheter, 22 III 1916, s. 1; Polska flyktingar i Sverge, Aftonbladet, 22 III 1916, s. 7; Alf DE Pomian, Polska förmedlingskommitten, Aftonbladet, 24 III 1916, s. 5.

${ }^{15}$ Organizacja polska $w$ Skandynawii, Kurier Lwowski, 11 IV 1916, s. 3-4; Odezwa komitetu polskiego w Sztokholmie, Głos Narodu, 11 IV 1916, nr 184, s. 1; Utworzenie Komitetu Polskiego w Sztokholmie, Nowa Reforma, 11 IV 1916, nr 184, s. 2; Komitet Polski w Sztokholmie, Dziennik 
$\mathrm{na}^{16}$ jako prezesa Komitetu. Informował on o fakcie powołania nowej organizacji charytatywnej w taki oto sposób: „W odczuciu rzeczywistej potrzeby,

Poznański, 11 IV 1916, nr 84, s. 3; Komitet Polski w Sztokholmie, Kurier Poznański, 12 IV 1916, nr 85, s. 8; Komitet Polski w Sztokholmie, Gazeta Polska, 14 IV 1916, nr 91, s. 2; Komitet Polski w Sztokholmie, Echo Polskie, 30 IV 1916, nr 16, s. 18; ANK, NKN, sygn. 52, k. 30.

${ }^{16} \mathrm{~W}$ tym momencie musimy wyjaśnić sprawę pisowni nazwiska A. de Pomiana tak przez niego samego, jak i autorów prac, którzy o nim pisali. Polscy historycy zapisywali nazwisko Alfonsa (Alfa) Karola dwuczłonowo: Pomian-Hajdukiewicz, łącząc nazwisko, jakie przybrał jego ojciec Józef Alfons Hajdukiewicz (1831-1873) po przybyciu do Szwecji w 1866 r., z nazwiskiem, jakie ten nosił po swoim ojcu Macieju Hajdukiewiczu przed wyjazdem z Rosji. Zob. np. Andrzej Piber, Pomian-Hajdukiewicz Alfons (Alf) Karol (1867-1972), [in:] Polski słownik biograficzny, t. 27, Wrocław 1982-1983, s. 381-382. Andrzej N. Uggla także stosuje pisownię dwuczłonową, jednak z pewnymi zmianami: Alf de Pomian Haydukiewicz, a także A. Pomian. Zob. A. N. UGGLA, Svensk-polska hjälpkommittéen, s. 102; idem, Rola Alfa de Pomiana-Haydukiewi$c z a$, s. 77-93. Pisownię dwuczłonową, odwróconą w kolejności pisania obu członów nazwiska, spotykamy także w źródłach z epoki, wytworzonych przez różnego rodzaju polskie instytucje i organizacje. Sam Alfons (Alf) Karol, jako poddany króla szwedzkiego, używał wyłącznie nazwiska przybranego przez jego ojca. Tak było przynajmniej do 1919 r. W naszych rozważaniach będziemy pisać nazwisko zgodnie z tym, jak czynił to jego właściciel. Pisownię stosowaną w polskich źródłach pozostawiamy bez zmian. Swego rodzaju ciekawostką jest używanie przez A. de Pomiana przed swoim nazwiskiem przyimka „de”, występującego w języku francuskim i innych językach w celu podkreślenia szlacheckiego pochodzenia. Zapewne chciał w ten sposób uwydatnić odmienną narodowość i zaakcentować szlachecki rodowód, co miało mu pomóc w kształtowaniu swojego wizerunku wśród społeczności szwedzkiej. O znaczeniu, jakie Szwedzi przykładali do wszelkiego rodzaju tytułów, wspomina w swojej relacji z podróży po Szwecji, odbytej w 1906 r., ks. Marcin Czermiński SJ: „Bacząc jednak na tutejsze zwyczaje, gdzie ludzie [... ] wzajemnie chętnie się tytułują i tytuły jeszcze popłacają, i my postanowiliśmy dostosować się do tej mody przez użycie tytułów nam przysługujących, których jednak zwyczajnie, jako zakonnicy nie używamy. O. Stolberg [SJ - S.W.] ma podwójne bilety szwedzkie, jedne z tytułem hrabiowskim, drugie jako pastor Stolberg. To też nazywałem przy Szwedach Ojca Stolberga: Herr Graf, on mnie tytułował Herr Doktor i tak się też prezentowaliśmy w salonach. Dzięki komedii z tytułami, wszędzie traktowano nas lepiej niż mają w zwyczaju obchodzić się ze swoimi pastorami, nieraz uważano sobie za zaszczyt gościć w swym domu o. Stolberga, co wszystko razem wzięte, bardzo nam ułatwiało pracę apostolską w kraju protestanckim, gdzie jeszcze dużo uprzedzeń przeciw katolickiemu Kościołowi i zabobonna trwoga przeciw papistom panuje”; Marcin Czermiński, Misje dla Polaków w Szwecji we wrześniu i październiku r. 1906, Missye Katolickie. Czasopismo Ilustrowane Miesięczne, R. 26: 1907, nr 5, s. 129-130. Z pewnej sztuczności tej formy zdawał sobie sprawę także A. de Pomian. O tym, jak dalece było to dla niego ważne, świadczy jego pisemna wypowiedź zawarta w postscriptum listu datowanego na $21 \mathrm{~V} 1919$ r., zaadresowanego do abpa Nathana Söderbloma. Pisząc o sprawach w żaden sposób niezwiązanych ze swoim nazwiskiem bądź pochodzeniem, w pewnym momencie, jakby dla usprawiedliwienia się przed N. Söderblomem z dopiero co złożonego podpisu, stwierdził: „De titlar en del polska släkter inneha äro alla givna dem av utländska regeringar. Min släkt har aldrig gjort sig förtjänt av någon sådan belöning från utländska makthavares sida och jag är därför endast polsk adelman utan titel” [„Tytuły szlacheckie będące w posiadaniu Polaków zostały im nadane przez rządy obcych państw. Moi krewni nigdy nie zasłużyli sobie na podobne wyróżnienie ze strony obcych mocarstw, stąd też jestem jedynie polskim szlachcicem bez tytułu" - S.W.]; List A. de Pomiana 
zrodzonej na tle doby obecnej w szczerem pragnieniu służenia sprawie ogólnej - grono Polaków przebywających w Szwecji powołało do życia samodzielną organizację polską w Skandynawii, która jako nowa placówka pracy narodowej i społecznej, ma wypełnić dotychczasową lukę w szeregu tych licznych organizacji polskich, które podjęły humanitarne hasła niesienia pomocy rodakom, dotkniętym przez wypadki wojenne. Instytucją tą jest niżej podpisany Komitet Polski w Sztokholmie"17.

Informacja zawarta w anonsie, mówiąca o inicjatywie powołania Komitetu przez działaczy polonijnych w stolicy Szwecji, została potwierdzona i wzmocniona przez A. de Pomiana prawie trzy lata później w raporcie datowanym na 24 I 1919 r. w Sztokholmie, skierowanym na ręce hrabiego Władysława Sobańskiego, londyńskiego przedstawiciela Komitetu Narodowego Polskiego w Paryżu. Kulisy powołania Komitetu A. de Pomian przedstawił następująco: „Założyciele byli oprócz parę osób polaków już przedtem w Stockholmie obsiadłych, polacy tu burzą wojenną zagnanych, ale wcale nie w tym celu nadesłanych. Wszystko to wskazuje, że [...] akcja polska była dorywcza i improwizowana" 18 .

Pierwsza z przytoczonych relacji informuje o zaistnieniu sztokholmskiego Komitetu w sposób bardzo lakoniczny. Autor nie wdaje się w szczegółowe roztrząsanie przyczyn i motywów ustanowienia nowej organizacji pomocowej. Milczy o genezie i inicjatorach jej powołania. Sposób prowadzenia narracji przez A. de Pomiana nie dziwi, jeśli weźmiemy pod uwagę charakter publikacji i jej cel, jakim było dotarcie do polskiego czytelnika $\mathrm{z}$ wiadomością o powołaniu Komitetu i jego zadaniach. Druga z relacji, przeznaczona wyłącznie dla W. Sobańskiego, jest bardziej emocjonalna. Pełno w niej błędów językowych i gramatycznych. Raport robi wrażenie, jakby pisano go w dużym pośpiechu i wysłano bez powtórnej redakcji. Wynikało to najprawdopodobniej z niedyspozycji zdrowotnej autora raportu. Wiemy, że między 19 a 24 I 1919 r. A. de Pomian chorował na grypę „hiszpankę”. Zapewne to ona miała wpływ na taką postać raportu' ${ }^{19}$.

do abpa N. Söderbloma, Sztokholm, 21 V 1919, Uppsala Universitetsbibliotek, Handskriftsregistret, Brev från Alf de Pomian (1867-1972).

${ }^{17}$ Dziennik Poznański, 11 IV 1916, nr 84, s. 3. Wybraliśmy to pismo codzienne, za którym przytaczamy treść anonsu, gdyż obok „Kuriera Lwowskiego” z 11 IV 1916 r. i „Gazety Polskiej” z 14 IV 1916 r. jedynie ta gazeta publikuje pełny tekst anonsu Komitetu Polskiego z 31 III 1916 r., bez żadnych skrótów i zmian odredakcyjnych.

${ }^{18}$ Raport A. de Pomiana skierowany na ręce hr. W. Sobańskiego, delegata Komitetu Narodowego Polskiego w Londynie, Sztokholm, 24 I 1919, Archiwum Akt Nowych w Warszawie (dalej cyt. AAN), Komitet Narodowy Polski w Paryżu (dalej cyt. KNP w Paryżu), sygn. 2031, k. 83.

${ }^{19} \mathrm{O}$ wpływie, jaki choroba wywarła na czynności służbowe A. de Pomiana, pisał on w raporcie do W. Sobańskiego: „Mam zaszczyt potwierdzić mój list z 19-tego b.m., [19 I 1919 - S.W.] wysłany przez kuriera legacji angielskiej, mój telegram z 22-go b.m. [22 I 1919 - S.W.]. Telegra- 
W przytoczonym fragmencie raportu z 24 I 1919 r. A. de Pomian zdecydowanie zaprzeczał jakiejkolwiek zewnętrznej inspiracji, która miałaby się przyczynić do powołania tej organizacji. Mało tego, informując W. Sobańskiego o ustanowieniu Komitetu, stwierdził, że była to akcja „dorywcza i improwizowana”. Relacja ta stoi w sprzeczności z tym, co A. de Pomian napisał prawie trzy lata wcześniej - w anonsie z 31 III 1916 r. W jego treści znajdujemy sformułowania mówiące o „dłuższych przygotowaniach” mających na celu powołanie Komitetu, o „odczuciu rzeczywistej potrzeby, zrodzonej na tle doby obecnej” czy o „szczerem pragnieniu służenia sprawie ogólnej”. Wszystkie przytoczone sformułowania nie zawierają w sobie elementów przypadkowości i improwizacji. Wręcz przeciwnie, robią wrażenie, że twórcy nowej organizacji charytatywnej działali z dużą determinacją i dokładali wszelkich starań, aby doprowadzić rzecz całą do pomyślnego końca. Czytając anons z 31 III 1916 r., odnosimy wrażenie, że działacze polonijni w Sztokholmie mieli zarówno określony plan działania, jak i dobrze znali cel, jaki chcieli osiągnąć.

Sposób narracji A. de Pomiana, jaki znajdujemy w raporcie z 24 I 1919 r. skierowanym do W. Sobańskiego, wiązał się z czasem i okolicznościami, w jakich dokument ten powstał. Listopad i grudzień 1918 r. oraz pierwsze miesiące roku 1919 były okresem ostrej rywalizacji politycznej o obsadę placówek dyplomatycznych, toczonej przez szeroko rozumiany obóz postaktywistyczny z paryskim Komitetem Narodowym Polskim, wspierającym powołany 16 I 1919 r. rząd Ignacego J. Paderewskiego. Jeżeli weźmiemy pod uwagę ubieganie się przez A. de Pomiana w tym właśnie momencie o posadę w tworzonym w Sztokholmie polskim przedstawicielstwie dyplomatycznym, to taka chęć odcięcia się od jakiejkolwiek zewnętrznej inspiracji wydaje się w pełni zrozumiała ${ }^{20}$. Z tego zapewne wynikała potrzeba podkreślenia inicjatywy miejscowej, czyli takiej, która narodziła się w Sztokholmie wśród potomków emigracji wcześniejszej i wojennych uchodźców. Łączenie w tym właśnie czasie narodzin sztokholmskiego Komitetu Polskiego z inną niż KNP opcją polityczną stwarzało dla A. de Pomiana jedynie same kłopoty, które nie pozwalały na osiągnięcie przez niego osobistych celów.

Odmienną wersję od tej, którą prezentuje A. de Pomian, znajdujemy w relacji matki U. Ledóchowskiej. Wartość znajdujących się tam informacji wydaje się istotna, biorąc pod uwagę to, że była ona naocznym świadkiem narodzin

my JW. Pana do Ministra Spraw Zagranicznych, jako też do p. Paderewskiego otrzymałem i natychmiast wysłałem przez radio tutejsze. Niestety, omieszkałem zawiadomić o tem JW. Pana, co tem się tłumaczy, że właśnie przez parę dni leżałem chory na hiszpankę"; ibid. k. 81.

${ }^{20}$ List A. de Pomiana do prezydenta rady ministrów I. J. Paderewskiego, Sztokholm, 10 II 1919, AAN, Archiwum I. J. Paderewskiego, sygn. 3650, k. 105-106. 
sztokholmskiego Komitetu. Matka Urszula zapamiętała moment powołania tej nowej organizacji pomocowej, a następnie odtworzyła z pamięci w spisanych w 1924 r. wspomnieniach: „Dość dużo Polaków było w Sztokholmie i to nasunęło pomysł zorganizowania oddzielnego Komitetu. Pierwszy poddał tę myśl pan Lednicki i wezwał mnie do współpracy" ${ }^{21}$.

Czy za przytoczonym sformułowaniem „oddzielnego Komitetu” kryje się coś więcej niż tylko zwrot retoryczny? Zdanie to napisane osiem lat od momentu rozegrania się wydarzeń straciło już swój autentyzm chwili, by wyciągać z niego zbyt daleko idące wnioski. Tym bardziej że w jej liście skierowanym do Michała Sokolnickiego, sekretarza generalnego Naczelnego Komitetu Narodowego w Krakowie, datowanym na 12 I 1916 r. w Djursholm pod Sztokholmem, nie ma wzmianki na temat powołania „oddzielnego Komitetu”, jest jedynie wiadomość o „utworzeniu się komitetu polskiego"22. Jeśli chodzi o fragment wspomnień matki U. Ledóchowskiej, w którym czytamy, że A. Lednicki wezwał ją do współpracy nad tworzeniem Komitetu (lub do współpracy z Komitetem), to z jego treści zdaje się wynikać, że prezes Rady Zjazdów zrobił to osobiście. Zapis ten jest jednak bardzo ogólny, a przez to mało precyzyjny. Taka możliwość kontaktu między matką Urszulą a prezesem Rady Zjazdów mogła nastąpić w lipcu 1916 r. W tym właśnie czasie A. Lednicki z Franciszkiem Skąpskim przejeżdżali koleją przez Szwecję, udając się do Christianii (ówczesna nazwa Oslo) na spotkanie z przybyłym z Londynu Augustem Zaleskim ${ }^{23}$. W tzw. kartach rejestru cudzoziemców z roku 1916 przechowywanych w kolekcji „Statens polisbyrö” w szwedzkim Archiwum Narodowym (Riksarkivet) brakuje jakiejkolwiek wzmianki odnoszącej się do A. Lednickiego. Wskazuje to na fakt, że drogę z Piotrogrodu do stolicy Norwegii obaj podróżnicy odbyli, nie zatrzymując się w żadnym ze szwedzkich miast. Gdyby było inaczej, ich pobyt w którymś z hoteli zostałby natychmiast odnotowany, a o ich dacie przyjazdu i wyjazdu powiadomiono by określoną terytorialnie Radę Powiatu (Länsstyrelsen). Procedura ta funkcjonowała zgodnie z zarządzeniem o ewidencji cudzoziemców na terytorium Szwecji, wydanym przez władze szwedzkie w lutym 1916 r. Zapisy w karcie rejestru cudzoziemców dotyczące A. Lednickiego pojawiają się dopiero w $1917 \mathrm{r}$. Informują one, że przybył on z Piotrogrodu do Sztokholmu 28 VIII 1917 r. i zamieszkał w Strand Hotell.

${ }^{21}$ U. LedóchowsKa, Historia Kongregacji Sióstr Urszulanek, s. 91.

${ }^{22}$ List J. Ledóchowskiej do M. Sokolnickiego, sekretarza generalnego Naczelnego Komitetu Narodowego w Krakowie, Djursholm, 12 I [1916], Archiwum Główne Urszulanek Serca Jezusa Konającego w Pniewach (dalej cyt. AGUSJK w Pniewach), Listy, t. 3: 1914-1918, s. 199 (mps $\mathrm{nr}$ 204). List ten przytacza w obszernych fragmentach także sam adresat; zob. Michał SoKoLNICKI, Rok czternasty, Londyn 1961, s. 337.

${ }^{23}$ Proces Lednickiego. Fragment $z$ dziejów odbudowy Polski 1915-1924, opr. Zygmunt WAsILEWSKI, Warszawa 1924, s. 197. 
W drogę powrotną wybrał się 11 IX 1917 r. $^{24}$ Brakuje także informacji na temat osobistych kontaktów z prezesem RZ POPOW we wspomnieniach matki U.Ledóchowskiej, co wskazuje, że spotkanie takie się nie odbyło. Gdyby do kontaktu takiego doszło, matka U. Ledóchowska, biorąc pod uwagę rangę osoby, na pewno by o tym pamiętała i nie omieszkałaby tego opisać w swoich wspomnieniach. Uważamy zatem za mało prawdopodobne, aby A. Lednicki mógł w tym czasie osobiście prowadzić rozmowy z matką Urszulą. Wykluczamy także list lub depeszę. W AGUSJK w Pniewach nie ma dokumentu, który wskazywałby na świadectwo jakiegokolwiek kontaktu między A. Lednickim a matką Urszulą. Należy raczej przypuszczać, że oferta współpracy została jej złożona w imieniu A. Lednickiego przez wysłanego do Sztokholmu emisariusza. Chyba że matka U. Ledóchowska potraktowała w ten sposób pismo, jakie otrzymała od Jerzego Zdziechowskiego, wiceprezesa RZ POPOW, datowane na 16/29 I 1916 r. w Moskwie ${ }^{25}$.

Podążając śladem wskazanym przez matkę U. Ledóchowską, napotykamy na fakty, które potwierdzają, że emigracja polska w Rosji była grupą, której przedstawiciele wykazywali szczególne zainteresowanie polskim wychodźstwem w Skandynawii. Zainteresowanie to wiązało się głównie z nową sytuacją, jaka ukształtowała się w wyniku zajęcia Warszawy i pozostałych ziem Królestwa Polskiego w sierpniu 1915 r. przez wojska mocarstw centralnych. W wyniku zaistniałych wydarzeń przerwane zostały istniejące dotychczas szlaki komunikacyjne i pocztowe między polskim wychodźstwem w Rosji a mieszkańcami ziem Królestwa. Ukształtowanie się frontów wojennych spowodowało, że przepływ informacji dramatycznie zmalał, przyczyniając się do licznych dezinformacji i powstawania plotek. Ograniczało to wiarygodność prasy dotychczas istniejącej i stwarzało nie lada przeszkodę dla redakcji tych pism, które właśnie tworzono. Sytuacja ta niezwykle utrudniała podejmowanie racjonalnych decyzji przez polskich polityków, którzy nie mieli możliwości korzystania z aparatu dyplomatycznego i służb wywiadowczych. Próbowano temu zaradzić przez tworzenie placówek korespondentów prasowych w miejscach, które z punktu widzenia polskich środowisk politycznych w Rosji i związanych z nimi organów prasowych mogły przynosić najwięcej korzyści. Regionem, który szczególnie nadawał się do tego typu roli, były kraje skandynawskie. $Z$ racji swojego położenia geopolitycznego, na ówczesnym etapie

${ }^{24}$ Riksarkivet, Stockholm, Statens polisbyrå, vol. E6:37, Lednicki Aleksander. W latach po wprowadzeniu przez Szwecję w 1918 r. obowiązku wizowego znajdujemy następujące wpisy dotyczące A. Lednickiego do karty rejestru wizowego: 26 I - 26 II 1918, 3 XII - 31 XII 1926, 2 X 1928 - 1 III 1929, 26 VIII - 25 X 1930; Riksarkivet, Stockholm, Utlänningskommission, vol. D1:52, Lednicki Aleksander.

${ }^{25}$ Pismo J. Zdziechowskiego, wiceprezesa RZ POPOW do hrabiny J. Ledóchowskiej, Sztokholm, 16/29 I 1916, AGUSJK w Pniewach. 
działań wojennych, Sztokholm i Kopenhaga cieszyły się wyjątkowym zainteresowaniem ${ }^{26}$.

W niedługim czasie po zajęciu Warszawy przez wojska niemieckie pojawił się w Sztokholmie Władysław Rabski ${ }^{27}$. Czy nastąpiło to jeszcze w sierpniu 1915 r., czy w kolejnych miesiącach, tego nie wiemy. Wiadomo, że w lipcu 1915 r. ewakuował się z Warszawy do Piotrogrodu, gdzie Komitet Narodowy Polski (KNP) powierzył mu kierowanie agencją prasową „Nord-Süd” w Sztokholmie. Centrala tej instytucji mieściła się w Piotrogrodzie. Agencja miała też filię w Kopenhadze ${ }^{28}$. Zaopatrywała ona w informacje polskie dzienniki w Rosji skupione wokół piotrogrodzkiego KNP, a także kolportowała w prasie krajów neutralnych materiały wymierzone przeciwko zwolennikom państw centralnych. Szczególnie silną pozycję zyskała placówka agencji w Kopenhadze, gdzie pisma duńskie chętnie cytowały przygotowywane przez „Nord-Süd” serwisy informacyjne ${ }^{29}$. Postaci W. Rabskiego poświęcimy tu więcej miejsca ze względu na rolę, jaką odgrywał wśród Polonii szwedzkiej. Wpływ, jaki wywierał na poglądy zgromadzonych w Sztokholmie polskich uchodźców, irytowały Stanisława Wędkiewicza jeszcze w październiku 1916 r., czyli w czasie, kiedy W. Rabski przebywał już Piotrogrodzie. Jemu to delegat Departamentu Wojskowego Naczelnego Komitetu Narodowego (NKN) przypisywał prokoalicyjny nastrój panujący wśród polskiej kolonii ${ }^{30}$. Prasa szwedzka przedstawiała swoim czytelnikom W. Rabskiego jako korespondenta polskich dzienników w Moskwie, Piotrogrodzie i Kijowie. Trzeba w tym miejscu podkreślić, że od momentu przybycia do stolicy Szwecji W. Rabski cieszył się w Sztokholmie niezwykłą estymą w sferach dyplomatycznych krajów Ententy i państw neutralnych ${ }^{31}$. Dotyczyło to także sił politycznych w Szwecji, które w opozycji do

${ }^{26}$ Stanisław Witkowski, Polska placówka prasowa $w$ Kopenhadze $w$ latach 1915-1917, Kwartalnik Historii Prasy Polskiej, R. 31: 1992, z. 1, s. 103-115.

${ }^{27}$ Stanisław DzIErzBicki, Pamiętnik z lat wojny 1915-1918, wstęp Janusz PAJEwski, opr. Danuta PŁygawko, Tomasz JodeŁkA-Burzecki, Warszawa 1983, s. 148. Dzierzbicki, relacjonując swój pobyt w Sztokholmie (19-26 VI 1916), napisał, że spotkał tam W. Rabskiego, „który przyjechał wkrótce po zajęciu Warszawy”.

${ }^{28}$ Rościsław Skręt, Rabski Władysław (1865-1925), [in:] Polski słownik biograficzny, t. 29, Wrocław 1986, s. 561-564; Irena Sputek, Polacy w Piotrogrodzie 1914-1917, Warszawa 1966, s. 426 .

${ }^{29}$ Raport S. Wędkiewicza dla dr. J. Dąbrowskiego, Sztokholm, 12 XI 1916 (odpis), ANK, NKN, sygn. 50, k. 256; Raport S. Wędkiewicza „Wieści ze Sztokholmu”, Sztokholm, 14 XI 1916 (odpis), ANK, NKN, sygn. 50, k. 280. .

${ }^{30}$ Pismo S. Wędkiewicza do M. Sokolnickiego, sekretarza generalnego NKN, Stockholm, Nybrogatan 6, 8 X [1916], ANK, NKN, sygn. 50, k. 138.

${ }^{31}$ Pisał o tym S. Dzierzbicki na kartach dziennika wkrótce po powrocie z misji do Sztokholmu z drugiej połowy czerwca 1916 r. W ten sposób autor zapisek nakreślił obraz W. Rabskiego: „Władysław Rabski [...] na raz flirtuje z czterema ambasadorowymi, głównie zaś ma być zawojowany przez lady Izabelę Howard. Nie mogę o tym sądzić, gdyż tak się złożyło, 
polityki rządu konserwatystów premiera Hjalmara Hammarskjölda i jego ministra spraw zagranicznych Knuta Wallenberga, sympatyzującego z państwami centralnymi, i aktywistów wspierających Niemcy i Austro-Węgry stały po stronie Ententy. Świadczy o tym m.in. to, że flagowy dziennik liberałów „Dagens Nyheter" zamieścił 19 IV $1916 \mathrm{r}$. na pierwszej stronie obszerny wywiad z wówczas wiceprezesem Komitetu Polskiego w Sztokholmie W. Rabskim i z jego zdjęciem podpisanym: „Dr Wladislaw von Rabski” ${ }^{2}$. Redakcja tego pisma przedstawiała swoim czytelnikom jego postać słowami: „Bland dem bemärkta utlänningar som under kriget sökt sig till Stockholm är också den polska skriftställaren och journalisten dr Wladislaw von Rabski, som för närvarande uppehåller sig här såsom korrespondent till polska tidningar i Petrograd, Kieff och Moskva. I Warschau har han senast varit politisk redaktör för den stora dagliga tidningen «Kurjev Warszarvski» och lämnade staden kort innan den tyska armén gjorde sitt intåg där. Då dr Rabski gjort sig mycket bekant i hemlandet ej blott som litteratör, utan även i egenskap av politiker - han har bl.a. förut varit ledare för det demokratiska ungpolska partiet i Posen och sedermera verkat för den liberala nationalismen i Polen - är han givetvis initierad i vad man för närvarande tänker i Polens politiska kretsar om situationen just nu och om landets öde efter världskriget. Hans synpunkter i denna fråga, som han i intervju delgivit av en «Dagens Nyheters» medarbetare, kunna därför påräkna allmännare intresse, om de också måhända förete en viss ensidighet" ${ }^{\prime 3}$.

że lady Izabeli nie poznałem z powodu chwilowego jej wyjazdu - podobno ma to być rzeczywiście elegancka i ładna dama. Natomiast w ciągu mojego pobytu najwięcej był zapraszany do pani Niekludow, ambasadorowej rosyjskiej, która ani urodą, ani elegancją nie grzeszy i ustępuje tak posłowej duńskiej, pani Scavenius, jak i amerykańskiej [...] pani Mac Truder”; zob. S. DzIERzBICKI, op.cit., s. 153.

${ }^{32}$ En polsk politiker om situationen. Intervju med skriftställaren dr Rabski. Polackerna vilja ej komma under tyskt ok, Dagens Nyheter, 19 IV 1916, s. 1. Zob. też Dr Rabski o sprawie polskiej [brak daty i podpisu, w tekście błędna data ukazania się wywiadu - 12 IV 1916], ANK, NKN, sygn. 52, k. 40. Referent prasowy NKN S. Wędkiewicz uznał wywiad na tyle istotny dla polityki krakowskiego komitetu, że dokonał tłumaczenia całego tekstu z niewielkimi skrótami. Ten sposób postępowania zdarzał się niezwykle rzadko. Najczęściej S. Wędkiewicz omawiał w kilku zdaniach określoną publikację.

${ }^{33}$ „Wśród wielu znaczących obcokrajowców, którzy podczas wojny trafili do Sztokholmu, jest także polski literat i dziennikarz Władysław von Rabski, który obecnie przebywa tu jako korespondent polskich gazet $\mathrm{z}$ Piotrogrodu, Kijowa i Moskwy. W Warszawie był on do niedawna redaktorem politycznym dużego dziennika «Kuriera Warszawskiego» i opuścił to miasto krótko przed wkroczeniem armii niemieckiej. Ponieważ dr Rabski zasłynął w ojczyźnie nie tylko jako literat, lecz także jako polityk - między innymi wcześniej, przywódca Demokratycznej Partii Młodo-Polskiej w Poznaniu, a następnie pracował na rzecz liberalnego nacjonalizmu w Polsce - jest on oczywiście zorientowany w tym, co obecnie myśli się w polskich kręgach politycznych o aktualnej sytuacji i o losie kraju po wojnie światowej. Jego poglądy w tej kwestii, którymi podzielił się w wywiadzie z dziennikarzem «Dagens Nyheter», mogą dlatego wzbudzić powszechne 
Należy przypuszczać, że nie bez znaczenia były osobiste walory W. Rabskiego: dar przekonywania, umiejętność argumentacji, talent oratorski, czar osobisty ${ }^{34}$. Były to cechy, które W. Rabski wykorzystywał w codziennej pracy dziennikarskiej w stolicy Szwecji. W połowie października 1915 r. notujemy inicjatywę A. Lednickiego, który próbował nawiązać kontakt z A. de Pomianem. W liście datowanym na 30 IX/13 X 1916 r. w Moskwie prezes moskiewskiego Komitetu Polskiego i jednocześnie wydawca dopiero co utworzonego tygodnika „Echo Polskie” złożył A. de Pomianowi ofertę współpracy: „Pragnąc służyć narodowym potrzebom współczesnej emigracji polskiej w Rosji, a zarazem najszerszym ideałom demokracji i postępu, z wyłączeniem ciasnej partyjności, rozpoczęliśmy wydawanie «Echa Polskiego». Chcemy zrzeszyć przy redakcji siły polskie, naszą ideę podzielające i dlatego zwracamy się do Sz. Pana z gorącą prośbą o współpracownictwo. W nadziei, że będziemy mogli zaliczyć Go do stałych współpracowników i przyjaciół naszego pisma, piszemy się z głębokim szacunkiem i poważaniem" ${ }^{35}$. Jak widać, oferta dotyczyła posady stałego korespondenta prasowego w Sztokholmie. Nie wiemy, jaka była reakcja A. de Pomiana na propozycję A. Lednickiego. W jednostce archiwalnej „Konsul Alf de Pomians arkiv”, wchodzącej w skład zbiorów Archiwum Krajowego w Vadstena (Landsarkivet i Vadstena), nie ma kopii odpowiedzi na tę ofertę. Prze-

zainteresowanie, nawet jeśli zdają się cechować pewną jednostronnością" [trans. i tłum. Agnieszka Kołaczek, konsultacja hist. - S.W.]. W tym miejscu musimy skomentować fragment tekstu w języku szwedzkim odnoszący się do działalności W. Rabskiego w Wielkopolsce. Stanęliśmy przed dylematem, czy zachować tekst tłumaczenia w dosłownym brzmieniu, czy też, jak zrobił to $\mathrm{S}$. Wędkiewicz, przetłumaczyć go niedosłownie, ale zgodnie z prawdą: „Dr. Rabski był jednym z przywódców stronnictwa narodowo-demokratycznego w Poznaniu”. Ostatecznie zachowaliśmy fragment tekstu w dosłownym brzmieniu, dodając jedynie komentarz. Jest bardzo prawdopodobne, że formuła ta powstała z inspiracji samego W. Rabskiego, aby szwedzka opinia publiczna, nieznająca polskich realiów, nie uznała go za przedstawiciela formacji skrajnie nacjonalistycznej. Osłabieniu tego wrażenia miała, jak przypuszczamy, służyć fraza, „że pracował na rzecz liberalnego nacjonalizmu w Polsce”. Przypuszczamy, że W. Rabski najprawdopodobniej czytał tekst przed jego opublikowaniem i taką formułę zaaprobował.

${ }^{34}$ Współczesny W. Rabskiemu Stanisław Lam wspominał go w następujący sposób: „[...] w gwarze redakcyjnym nabierał werwy, komentował każdą depeszę, przypominał podobne zdarzenia - trzeba przyznać, że pamięć miał fenomenalną. [...] Pisał bardzo szybko [...], czytał niewiele, ale umiał kartkować każdą książkę i wyciągnąć z niej to, co mu było potrzebne. Opierał się często na zasłyszanym, toteż chętnie bywał wszędzie, gdzie spotykało się większe towarzystwo"; zob. Stanisław LaM, Życie wśród wielu, Warszawa 1968, s. 221. Z kolei Konrad Olchowicz zwrócił uwagę na jego cechy osobiste: „Na przekór agresywności pióra [...] w życiu osobistym [...] był Rabski sympatyczny, łatwy w obejściu, ujmujący, uczynny [...] w sumie człowiek czarujący"; zob. Konrad Olchowicz, Ćwierć wieku z „Kurierem Warszawskim”, Kraków 1974, s. 39. Podobnie pisał S. DzierzBicki, op.cit., s. 160: „Władysław Rabski, z którym mnie łączą dawne koleżeńskie stosunki [...] zawsze bardzo miły i inteligentny kompan [...]".

${ }^{35}$ Pismo A. Lednickiego w imieniu redakcji Echa Polskiego do A. de Pomiana, Moskwa, 30 IX/13 X 1915 Landsarkivet i Vadstena, Konsul Alf de Pomians arkiv, [brak paginacji]. 
glądając strony „Echa Polskiego”, z całą pewnością można stwierdzić, że redakcja tego tygodnika w latach 1915-1916 nie opublikowała na swych łamach ani jednej korespondencji A. de Pomiana. Mało tego, do końca 1915 r. brakuje tam jakiejkolwiek korespondencji nadesłanej ze Sztokholmu. Dlatego z dużym prawdopodobieństwem możemy przyjąć tezę, że A. de Pomian z nieznanych nam bliżej powodów nie przyjął oferty A. Lednickiego. Odmowa A. de Pomiana, wyrażona zapewne w formie milczącej, zmusiła prezesa moskiewskiego Komitetu Polskiego i redakcję „Echa Polskiego” do poszukiwań innego kandydata. Znaleziono go już wkrótce w Kopenhadze w osobie Włodzimierza Pińskiego, korespondenta prasowego „Dziennika Poznańskiego” i „Kuriera Poznańskiego”. Według relacji S. Wędkiewicza, referenta prasowego pism skandynawskich przy Naczelnym Komitecie Narodowym, a następnie, od września 1916 r., agenta prasowego Departamentu Wojskowego NKN w Sztokholmie, W. Piński był autorem „przychylnym koalicji” i „rusofilskich korespondencji” tak w obu poznańskich dziennikach, jak i pismach w Ameryce i Rosji ${ }^{36}$. Od tej pory W. Piński stał się stałym korespondentem „Echa Polskiego” w tym rejonie Europy ${ }^{37}$.

Kontynuacją zainteresowań polskim wychodźstwem w stolicy Szwecji wypływających z kręgu politycznego A. Lednickiego była sztokholmska misja Józefa Everta, wiceprezesa moskiewskiego Komitetu Polskiego, członka Wydziału Wykonawczego Rady Zjazdów ${ }^{38}$. Późną jesienią 1915 r. przebywał on w stolicy

${ }^{36}$ Sprawozdanie z Danii i Szwecji, Sztokholm, 23 IX 1916, ANK, NKN, sygn. 50, k. 121; Sprawozdanie z Szwecji, Sztokholm, 26 X 1916, ANK, NKN, sygn. 50, k. 184; Odpis pisma S. Wędkiewicza do J. Dąbrowskiego, Sztokholm, 22 XI 1916, ANK, NKN, sygn. 50, k. 343.

${ }^{37}$ Pierwsza korespondencja nadesłana przez W. Pińskiego z Kopenhagi pojawiła się na łamach „Echa Polskiego” w numerze 10 z 15/28 XI 1915 r. Korespondencja datowana była na 5 XI 1915 r. i podpisana kryptonimem „Ski”, którego używał W. Piński. Zob. Wieści z kraju, Echo Polskie, 15/28 XI 1915, nr 10, s. I-II; Wyjątek z referatu „Dania” śp. Teodorowicza skopiowany w delegacji raperswilskiej 18 VII 1916 r., ANK, NKN, mikrof. 100241, k. 13.

${ }^{38}$ Józef Ludwik Evert (1863-1945) - osiadł w Rosji w 1896 r. Pełnił tam funkcję przedstawiciela znanej łódzkiej firmy włókienniczej Scheibler i Grohman na Rosję europejską i azjatycką. Od 1900 r. był obok A. Lednickiego czołowym działaczem kolonii polskiej w Moskwie. Uczestniczył w życiu społecznym Polonii moskiewskiej, biorąc udział w pracach Rzymskokatolickiego Towarzystwa Dobroczynności (RTD), którego prezesem był A. Lednicki. Od chwili, gdy w pierwszych miesiącach wojny A. Lednicki utworzył przy RTD agendę pod nazwą Komitet Polski Pomocy dla Ofiar Wojny (KPPOW), J. Evert stał się jej czołowym działaczem. Po zarejestrowaniu Komitetu przez moskiewski Urząd do Spraw Stowarzyszeń (czerwiec 1915 r.) 6/19 VIII 1915 r. walne zgromadzenie KPPOW powierzyło J. Evertowi funkcję wiceprezesa. Objął on także kierownictwo nad Wydziałem Organizacyjnym Komitetu. Ta jednostka organizacyjna była tym instrumentem, który pozwalał odgrywać jej kierownikowi rolę znacznie ważniejszą niż pełnienie tylko funkcji zastępcy A. Lednickiego. Można powiedzieć, że od chwili wyboru A. Lednickiego na przewodniczącego Rady Zjazdów POPOW i prezesa Wydziału Wykonawczego tej instytucji, to J. Evert faktycznie kierował moskiewskim Komitetem Polskim. Pozostałymi 
Szwecji. Relacja z tego pobytu, zatytułowana W Królestwie, Niemczech i Szwecji, ukazała się na łamach moskiewskiej „Gazety Polskiej” 2/17 XII 1915 r. ${ }^{39}$ Publikacja ta dla naszych rozważań wydaje się szczególnie interesująca, ponieważ pozwala $\mathrm{w}$ jakimś zakresie pokusić się o próbę rekonstrukcji wydarzeń, jakie zaszły w stolicy Szwecji, a następnie w Piotrogrodzie i Moskwie, a które w konsekwencji mogły doprowadzić, bądź doprowadziły, do powołania Komitetu Polskiego w Sztokholmie. Zadanie to niełatwe ze względu na skąpe i jednostronne informacje zawarte w tej relacji. Przyjrzyjmy się jednak bliżej tej publikacji, by prześledzić, czym J. Evert chciał i mógł się podzielić z czytelnikami i jak komentowała jego słowa redakcja dziennika.

Publikacja miała formę wywiadu. Jej treść dotyczyła, jak pisano, „dopiero co" odbytej podróży J. Everta do Sztokholmu. Według jego relacji była to jego druga wyprawa do stolicy Szwecji, którą odbył w 1915 r. Pierwszy raz gościł

członkami zarządu byli: Wacław Purski (skarbnik), Antoni Bellier (sekretarz), Stefan Byszewski (zastępca sekretarza). Odgrywali oni znacznie mniejszą rolę. Józef Evert, jako przedstawiciel Komitetu Polskiego w Moskwie, wchodził w skład Wydziału Wykonawczego Rady Zjazdów POPOW. Wartą przytoczenia, choć niepozbawioną dużego subiektywizmu, charakterystykę J. Everta znajdujemy we wspomnieniach syna A. Lednickiego, Wacława: „Józef Evert przedstawiciel $[. .$.$] łódzkiej manufaktury tekstylnej, był przystojnym człowiekiem skromnego pocho-$ dzenia. Ale sam pan Józef Evert podkreślał z dumą stare protestanckie tradycje rodziny. [...] Evert dowodził, że jego rodzina pochodziła od kalwinistów francuskich i że jego przodkowie znaleźli się w Polsce w czasie prześladowań religijnych we Francji. Mimo, że pan Józef, jak się wydaje, wyższego wykształcenia nie zdobył, bardzo szybko stał się jednym z najbardziej aktywnych i wybitnych członków kolonii polskiej w Moskwie. W ciągu kilkunastu lat, przed katastrofą rosyjską, ten stały wiceprezes $\mathrm{w}$ rozmaitych naczelnych instytucjach i organizacjach polskich wykazywał duże zdolności i takt, chociaż nie był całkiem wolny od pewnego snobizmu i pretensyi. Nabył ładny dom, który (wraz ze swoją malutką i nieładną żoną) nader przytulnie urządził i umeblował. Oboje lubowali się w odgrywaniu roli starych patrycjuszów moskiewskich. Na początku swej kariery społecznej i towarzyskiej nie zawsze wiedział, jak trzeba się ubrać, a więc nieraz pojawiał się na śniadaniu w smokingu. Później nauczył się i zawsze bardzo dbał o swoje staranne i właściwe ubranie. Ojciec mój szybko zorientował się w jego uzdolnieniach i wprowadził go do swojej działalności politycznej. W czasie pierwszej wojny światowej Evert stał się jednym z najaktywniejszych współpracowników ojca we wszystkich jego społecznych i politycznych poczynaniach. [...] Był całkiem dobrym mówcą, starannie opracowywał styl swoich przemówień, ozdabiał je cytatami z łaciny i autorów polskich, co można nazwać nie lada dokonaniem, ale ten samouk posiadał bogatą bibliotekę i dużo czytał. Bardzo był towarzyski, gościnny i ofiarny"; zob. Wacław Lednicki, Pamiętniki, t. 2, Londyn 1967, s. 242, 263-264; Aleksander Lednicki, Pamiętnik 1914-1918, wstęp i opr. Zbigniew Koziński, Kraków 1994, s. 25, przyp. 9; Halina Evert-Kappesowa, Evert Ludwik Józef (1863-1945), [in:] Polski stownik biograficzny, t. 6, Kraków 1948, s. 323-324.

${ }^{39}$ W Królestwie, Niemczech i Szwecji (wywiad z p. J. Evertem), Gazeta Polska, 4/17 XII 1915, $\mathrm{nr} 42$, s. 1-2. Obszerne fragmenty wywiadu z J. Evertem dotyczące jedynie sprawy polskiej na terenie Szwecji przedrukował za „Gazetą Polską” wydawany w Piotrogrodzie „Dziennik Petrogradzki”. Zob. Sprawy polskie za granica. Szwecja, Dziennik Petrogradzki, 22 XII 1915, nr 1656, s. 2. 
w tym mieście w maju tegoż roku. Nie znamy przyczyn ani rezultatów jego majowej wizyty w Sztokholmie ${ }^{40}$. Redakcja "Gazety Polskiej” nadała tej publikacji szczególną rangę. Wywiad z J. Evertem, z niewielkim odredakcyjnym komentarzem, zapełniał cztery szpalty na pierwszej stronie i półtorej szpalty na stronie drugiej. Około $3 / 4$ tekstu stanowiła relacja odnosząca się do sytuacji na ziemiach polskich, które znalazły się w sierpniu $1915 \mathrm{r}$. pod okupacją niemiecką. Niewielki fragment dotyczył sytuacji ekonomicznej w samych Niemczech. Pozostała część tekstu - najbardziej nas interesująca - opisywała sprawy polskiego wychodźstwa w stolicy Szwecji. Ograniczenia związane z wojskową cenzurą, jakiej podlegał dziennik, wyznaczały nieprzekraczalne granice tak dla potrzeb, jak i chęci informacyjnych redakcji. To, że J. Evert przywiózł z pobytu w Sztokholmie znacznie więcej wiadomości interesujących polską emigrację w Rosji niż te, które ujawnił publicznie czytelnikom „Gazety Polskiej”, wydaje się sprawą oczywistą.

Na wstępie redakcja periodyku w sposób bardzo krótki informowała o terminie wyjazdu J. Everta i jego celach. Pisano, że wiceprezes Komitetu Polskiego w Moskwie udał się do stolicy Szwecji ,w interesach handlowych w d. 10 zeszłego miesiąca". Przyjmujemy, że data 10 XI 1915 r., o której pisze redakcja „Gazety Polskiej”, jest podana według kalendarza juliańskiego, co w przeliczeniu na kalendarz gregoriański odpowiada 23 XI $1915 \mathrm{r}^{41}$ To wszystko, co wiemy o przyczynach i dacie tej podróży.

Środowisko skupione wokó A. Lednickiego przygotowywało podróż J. Everta już od pewnego czasu, co potwierdzają decyzje organizacyjne podjęte 27 X/9 XI 1915 r. na posiedzeniu zarządu moskiewskiego Komitetu Polskiego. Jak informowało „Echo Polskie”, w związku z wyjazdem J. Everta do Sztokholmu zarząd obradujący pod kierownictwem A. Lednickiego podjął uchwałę, aby „wzmocnić skład prezydium”. Zamierzano to osiągnąć przez wprowadzenie dyżurów przewodniczących wydziałów Komitetu w godzinach urzędowania nieobecnego J. Everta ${ }^{42}$. Działania władz Komitetu wskazują, że liczono się z tym, iż pobyt J. Everta w stolicy Szwecji może potrwać na tyle długo, że zakłóci to statutową działalność tej organizacji. Wyjazd do Sztokholmu wiceprezesa moskiewskiego Komitetu Polskiego i członka Wydziału Wykonawczego Rady Zjazdów w jednej osobie był zatem najprawdopodobniej czymś więcej niż jedynie podróżą „,W interesach handlowych". Można pokusić się o przypuszczenie, że J. Evert udawał się do stolicy Szwecji z określoną misją. Informowanie o wyprawie J. Everta post factum na łamach „Gazety Polskiej” jako

${ }^{40}$ Gazeta Polska, 4/17 XII 1915, nr 42, s. 1-2.

${ }^{41}$ Ibid.

${ }^{42}$ Posiedzenie Zarządu K.P. $z$ dnia 27 października, Echo Polskie. Dodatek Literacki, 8/21 XI 1915, nr 9, s. V. 
o wyjeździe w celach jedynie handlowych wydaje się próbą ukrycia jej rzeczywistych intencji.

Data przybycia J. Everta do Sztokholmu pozostaje nieznana. Ktoś, kto chciał w tym czasie dotrzeć z Moskwy do Sztokholmu lub innego miejsca w Danii, Norwegii, Wielkiej Brytanii, Francji, Szwajcarii lub Stanach Zjednoczonych, w pierwszej kolejności musiał udać się do Piotrogrodu, gdzie w stolicy państwa carów rozpoczynała swój bieg linia kolejowa, będąca w tym czasie główną drogą komunikacyjną łączącą Rosję z zachodem Europy. Z Piotrogrodu należało jechać koleją przez Finlandię do granicznej stacji w Torneå, tam kończyła się rosyjska część szlaku. W Torneå pasażerów czekała odprawa paszportowa i celna, którą przeprowadzały służby rosyjskie. Następnie podróżujący musieli przebyć kilkanaście kilometrów do stacji Happaranda, położonej po szwedzkiej stronie granicy. Aby pokonać ten odcinek drogi, należało, w zależności od pory roku, przepłynąć go promem, a jeżeli Zatoka Botnicka była zamarznięta, przejechać na saniach ciągniętych przez konie lub renifery ${ }^{43}$. Po stronie szwedzkiej ponownie poddawano podróżujących kontroli paszportowej, a także sanitarnej ${ }^{44}$.

Po wyczerpującej, trwającej kilka godzin procedurze pozwalano wojażerom wyruszyć kolejowym ekspresem w dalszą drogę do stolicy Szwecji. Cała podróż z Piotrogrodu do Sztokholmu trwała trzy doby ${ }^{45}$. Jeżeli zatem weźmiemy pod uwage wariant, że J. Evert wyjechał z Moskwy - jak pisze „Gazeta Polska” - 10/23 XI 1915 r., najprawdopodobniej około godziny 19, to po ok. 14 godzinach podróży, w dniu następnym, 11/24XI 1915 r. o godzinie dziewiątej rano z minutami przybył do stolicy państwa carów ${ }^{46}$, po czym, bez zbędnej zwłoki, udał się na Dworzec Fiński i jeszcze tego samego dnia wyjechał z Piotrogrodu do Sztokholmu, to można bez większego błędu przyjąć, że J. Evert do stolicy

${ }^{43}$ Józef ZIABICKI, Wspomnienia (maszynopis udostępniony autorowi artykułu przez prof. dra hab. Andrzeja Ziabickiego), s. 21/III; Pamiętnik księżnej Marii Zdzisławowej Lubomirskiej 1914-1918, red. Janusz Pajewski, opr. Aleksandra KosickA-PAJEwska, Poznań 1997, s. 263.

${ }^{44}$ J. ZIABICKI, op.cit., s. 21/III.

${ }^{45}$ Pamiętnik księżnej Marii Zdzisławowej Lubomirskiej, s. 257, 259, 263-264; J. ZIABICKI, op.cit., s. 20-21/III. Zob. też inne relacje: Jan J. Kowalczy , Z Warszawy do Kopenhagi, Gazeta Warszawska, 16 V 1915, nr 134, s. 2; Włodzimierz Pıński, W Piotrogrodzie podczas wojny, Dziennik Poznański, 12 I 1917, nr 8, s. 1-2 (przytacza relację z podróży Vigga Toepfera, opublikowaną na łamach „Politiken”). Stanisław Domaszowski, który podróżował z Piotrogrodu do Sztokholmu w maju 1916 r., pisze, że podróż trwała „siedemdziesiąt kilka godzin”; zob. Stanisław Domaszowski, Z wycieczki do Skandynawji, Gazeta Polska, 5/18 VI 1916, nr 153, s. 1-2.

${ }^{46} \mathrm{O}$ tej godzinie odjeżdżał pociąg z Moskwy do Piotrogrodu, którym do stolicy często podróżował A. Lednicki. Pociąg ten „przychodził [do Piotrogrodu - S.W.] rano o godzinie $9 \mathrm{z}$ minutami”; zob. Mieczysław Smoleń, Działalność polityczna Aleksandra Lednickiego w Rosji (dysertacja doktorska przechowywana w Archiwum Biblioteki Jagiellońskiej, dokt. 39/80), Kraków 1979, s. 234, przyp. 49; A. LEDNICKI, op.cit., s. 53. 
Szwecji przybył 27 XI 1915 r. (według czasu tam obowiązującego) między godziną dziewiątą a jedenastą̨7 . Jeżeli zaś przebywał w Piotrogrodzie dłużej, wypoczywając lub prowadząc jakieś konsultacje i rozmowy, to każdy następny dzień spędzony w stolicy Rosji będzie przesuwał datę przybycia J. Everta do Sztokholmu na termin późniejszy. Podsumowując te rozważania, można przyjąć, że 14/27 XI 1915 r. to najwcześniejszy termin, w jakim wiceprezes Komitetu Moskiewskiego mógł przyjechać do stolicy Szwecji.

Jak długo trwał pobyt J. Everta w Sztokholmie, nie wiadomo. Podobnie jak w przypadku ustalania daty przybycia wiceprezesa moskiewskiego Komitetu Polskiego do stolicy Szwecji, pozostaje nam tylko próba ustalenia prawdopodobnego terminu jego powrotu do Moskwy. Według informacji zamieszczonych na łamach wydawanego w Moskwie przez A. Lednickiego tygodnika „Echo Polskie” wiemy z całą pewnością, że J. Evert nie uczestniczył w posiedzeniu zarządu moskiewskiego Komitetu Polskiego 17/30 XI 1915 r. i w dwóch posiedzeniach „narady specjalnej dla unormowania budżetu KP”, które odbyły się 23 XI/6 XII i 26 XI/9 XII 1915 r. ${ }^{48}$ W dniu 4/17 XII 1915 r. „Gazeta Polska” - jak pamiętamy - opublikowała wywiad z J. Evertem, informując czytelników o jego powrocie ze Sztokholmu ${ }^{49}$. Dzień później, czyli 5/18 XII $1915 \mathrm{r}$. wziął już udział w posiedzeniu moskiewskiego Komitetu Polskiego, o czym donosiło „Echo Polskie” ${ }^{50}$.

Jeżeli przyjmiemy, że podróż ze stolicy Szwecji do Piotrogrodu, jak stwierdziliśmy, trwała trzy doby i nie była po jej zakończeniu przedłużona jedno- lub kilkudniowym pobytem $\mathrm{w}$ stolicy Rosji, a następnie dodamy czas (ok. 14 godzin) potrzebny na przejazd pociągiem z Piotrogrodu do Moskwy, to można przyjąć, że termin, w którym J. Evert najpóźniej mógł wyjechać ze Sztokholmu, to 11 XII $1915 \mathrm{r}$. (tamtego czasu). Tylko w takim przypadku mógł 2/15 XII 1915 r. powrócić do miejsca swego zamieszkania, aby następnego dnia (3/16 XII 1915) udzielić wywiadu redakcji dziennika. W kolejnym dniu (4/17 XII 1915) wywiad ukazał się w „Gazecie Polskiej”. Zatem najdłuższy domniemany czas, jaki mógł J. Evert spędzić w Sztokholmie, rozciąga się między 14/27 XI 1915 r. a 29 XI/11 XII 1915 r. Jak nietrudno obliczyć określony przez nas powyżej, domniemany maksymalny czas pobytu J. Everta w stolicy Szwecji mógł wynieść ok. 14 dni. Możemy się tu mylić in plus o jakieś dwa dni, ale

${ }^{47}$ Pamiętnik księżnej Marii Zdzisławowej Lubomirskiej, s. 264. Domaszowski przybył do Sztokholmu o godzinie dziewiątej rano; zob. S. DomaszowsKi, op.cit., s. 1.

${ }^{48}$ Komitet Polski pomocy dla ofiar wojny w Moskwie, Echo Polskie, 29 XI/12 XII 1915, nr 12, s. VI; Komitet Polski pomocy dla ofiar wojny w Moskwie, Echo Polskie. Dodatek literacki, 6/19 XII 1915, nr 13, s. V-VI.

${ }^{49}$ Gazeta Polska, 4/17 XII 1915, nr 42, s. 2.

${ }^{50}$ Komitet Polski pomocy dla ofiar wojny w Moskwie, Echo Polskie. Dodatek literacki, 13/26 XII 1915, nr 14, s. V-VI. 
prawdopodobnie nie więcej. Cała ta wyprawa, na którą składała się podróż w obie strony wraz z pobytem w Sztokholmie, według naszych obliczeń zajęła więc J. Evertowi najprawdopodobniej 23 doby.

Powróćmy teraz do omawianej publikacji „Gazety Polskiej”. Redakcja dziennika za J. Evertem podaje przyczyny, dla których wiceprezes moskiewskiego Komitetu Polskiego udał się do stolicy Szwecji. Czytamy tam, że podróż

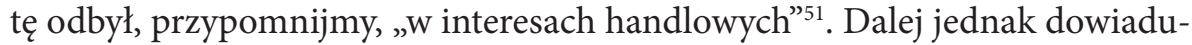
jemy się, że J. Evert w czasie swojego pobytu w Sztokholmie spotkał się „z kilku poważnymi rodakami, świeżo przybyłymi z Królestwa” ${ }^{52}$. Charakteryzował on swoich rozmówców jako ludzi poważnych i spostrzegawczych ${ }^{53}$.

Powyższa charakterystyka najprawdopodobniej dotyczyła osób (lub osoby), które J. Evert znał i którym ufał, a one z kolei ufały jemu. Jak wynika z relacji wiceprezesa moskiewskiego Komitetu, napotkani w Sztokholmie rozmówcy, według jego oceny, udzielili mu bardzo wielu szczegółowych i kompetentnych informacji. Dotyczyły one różnych sfer życia tak w samej Warszawie, jak i pozostałej części Królestwa, które znalazły się pod okupacją Niemiec. Osoby te, jak czytamy, nie ukrywały przed J. Evertem swoich poglądów wobec polityki realizowanej wobec Królestwa przez niemieckie władze okupacyjne. Kim byli rozmówcy J. Everta? Na tak postawione pytanie niestety nie jesteśmy w stanie odpowiedzieć. Jedno tylko wydaje się pewne. Nie byli to z pewnością zwykli wychodźcy z Królestwa, bawiący przejazdem w Sztokholmie, udający się do państw Europy Zachodniej lub, co jeszcze mniej prawdopodobne, do Rosji. Były to zapewne osoby (lub osoba), które cieszyły się szczególnym zaufaniem władz niemieckich. Najprawdopodobniej miały (miał) specjalne paszporty (paszport) pozwalające (pozwalający) bez żadnej zwłoki odbyć podróż z Warszawy do Sztokholmu. Ktoś, kto takich względów u władz niemieckich nie miał, zmuszony był przez kilka tygodni oczekiwać na niemiecki paszport bez jakiejkolwiek gwarancji, że go otrzyma. Dlaczego tak sądzimy? Z informacji zawartych w relacji opublikowanej na stronach „Gazety Polskiej” wynika, że 29 XI 1915 r. (według nowego stylu) osoby (lub osoba) prawdopodobnie znajdowały (znajdowała) się jeszcze w Warszawie. Opowiadały (opowiadała) bowiem w Sztokholmie J. Evertowi o tym, jak to niemieckie władze okupacyjne w Warszawie zapowiedziały uroczyste obchody rocznicy powstania listopadowego, po czym rano tego właśnie dnia odwołały całą uroczystośćs4. Biorąc pod uwagę tak krótki okres, po jakim rozmówcy (rozmówca) J. Everta znaleźli (znalazł) się w Sztokholmie, przypomnijmy - J. Evert ok. 11 XII 1915 r.

\footnotetext{
${ }^{51}$ Gazeta Polska, 4/17 XII 1915, nr 42, s. 2.

52 Ibid.

${ }^{53}$ Ibid.

${ }^{54}$ Ibid.
} 
opuścił to miasto - musiały (musiał) dysponować paszportem, który otrzymały (otrzymał) w sposób niezwykle szybki, można powiedzieć: specjalny. Takim specjalnym, tzw. cesarskim paszportem, dysponował mieszkający w Berlinie Franciszek Ksawery książę Drucki-Lubecki, właściciel ziemski w Wielkopolsce, dziedziczny członek pruskiej Izby Panów, właściciel dziennika „Kraj”, który od lutego 1915 r. był członkiem zarządu Poznańskiego Komitetu Niesienia Pomocy Królestwu Polskiemu. Jak pisze w pamiętniku S. Dzierzbicki, F. K. Drucki-Lubecki pełnił funkcję pośrednika w kontaktach między przybywającymi z Rosji do Sztokholmu wysłannikami polskich organizacji charytatywnych a przedstawicielami analogicznych instytucji w Królestwie ${ }^{55}$.

Jest też inna możliwość. Osoby (lub osoba), z którymi (którą) J. Evert spotkał się w Sztokholmie, mogły (mogła) mieszkać w Berlinie lub zaborze pruskim, a jedynie czasowo przebywać w Warszawie. Mogły (mogła) znać sytuację w Królestwie, pochodzącą z kół zbliżonych do władz niemieckich. Sugerować to może ten fragment wywiadu, w którym J. Evert, odpowiadając na pytanie dziennikarza "Gazety Polskiej” o sytuację w Niemczech, stwierdza, że co prawda w Niemczech nie był, ale zaraz oświadcza, że rozmawiał „z wielu poważnymi rodakami, którzy byli świeżo w Berlinie" 56 .

Czy było to zatem przypadkowe spotkanie, czy też wcześniej umówione, na które przybył J. Evert jako wysłannik A. Lednickiego, aby zasięgnąć informacji o sytuacji w Królestwie po zajęciu go przez wojska państw centralnych w sierpniu 1915 r.? Sądzimy, że ta druga możliwość jest bardzo prawdopodobna, chociaż w zasadzie jedno nie wyklucza drugiego. Wiadomo, że jesienią $1915 \mathrm{r}$. A. Lednicki i bliskie mu politycznie osoby, do których zaliczał się J. Evert, zaczęły kierować swoje polityczne zainteresowanie w stronę obozu aktywistycznego, którego reprezentantem na gruncie rosyjskim było piotrogrodzkie Zrzeszenie Niepodległościowe. Zainteresowanie to wiązało się przede wszystkim z brakiem działań rządu rosyjskiego w kwestii polskiej, a także sprzeciwem wobec polityki Koła Polskiego w rosyjskiej Dumie Państwowej. Świadczy o tym cytowany przez Mieczysława Smolenia raport carskiej policji. Czytamy w nim, że 5/18 IX 1915 r. w redakcji „Echa Polskiego” pod przewodnictwem J. Everta odbyło się spotkanie polskich dziennikarzy, literatów i działaczy społecznych. W czasie tego zebrania, które miało charakter polityczny i opozycyjny, mówcy mieli krytykować decyzje rosyjskich władz administracyjnych w kwestiach dotyczących statusu wychodźców z Królestwa w Rosji, a także wskazywali na to, że w chwili opuszczenia przez wojska rosyjskie ziem Królestwa Rosja utraciła prawa do Polski. Idąc dalej w swych rozważaniach, zebrani wyciągali wniosek, że w zaistniałej sytuacji Polacy „powinni

\footnotetext{
${ }^{55}$ S. DzIERZBiCKI, op.cit., s. 145-150.

${ }^{56}$ Gazeta Polska, 4/17 XII 1915, nr 42, s. 2.
} 
być gotowi i do tego, aby w razie potrzeby chwycić za broń do walki z Rosją broniąc swej politycznej niezawisłości" ${ }^{57}$.

Czas, w którym J. Evert pojawił się w stolicy Szwecji, był okresem szczególnej aktywności polskiego środowiska emigracyjnego w tym kraju, działającego na rzecz stałej obecności kwestii polskiej wśród skandynawskiej opinii publicznej. Dotyczyło to przede wszystkim działań matki U.Ledóchowskiej, która prowadziła je z inspiracji Komitetu Veveyskiego. Akcja ta, której głównym celem było zbieranie funduszy na rzecz mieszkańców ziem polskich, cierpiących nędzę w wyniku prowadzonych na tym obszarze działań wojennych, miała także inny cel, mianowicie propagowanie wśród społeczeństw krajów skandynawskich niepodległościowych aspiracji polskiego narodu ${ }^{58}$.

W czasie pobytu J. Everta w Sztokholmie Komitet Veveyski czynił starania u władz szwedzkich w sprawie zakupu żywności na terenie tego kraju i dostarczenia jej na ziemie Królestwa okupowane przez państwa centralne. W sprawie tej Henryk Sienkiewicz i Antoni Osuchowski wysłali już 23 IX 1915 r. pismo do honorowego konsula Szwajcarii w Sztokholmie Nilsa E. Frykholma ${ }^{59}$. Informacje na temat tej inicjatywy znajdujemy także w wywiadzie J. Everta dla „Gazety Polskiej”. Czytamy tam, że Szwedzi w Sztokholmie zamierzają powołać „specjalny Komitet Polski”, którego podstawowym zadaniem miało być organizowanie pomocy żywnościowej dla okupowanego Królestwa. W tym celu planowano, w porozumieniu z Komitetem Veveyskim, urządzenie w całej Skandynawii „dnia polskiego”. Za pieniądze pochodzące $\mathrm{z}$ tej akcji chciano zakupić żywność, a następnie wysłać ją do Warszawy. Jak informował dalej J. Evert, rząd niemiecki miał się zobowiązać do nierekwirowania nabytych towarów. Przewidywano, że na miejscu w Warszawie będą one rozdysponowane pod nadzorem szwedzkich konsulów ${ }^{60}$.

W przytoczonym fragmencie jest mowa o inicjatywie powołania w Sztokholmie organizacji o nazwie „Komitet Polski”. Propozycja ta według J. Everta miała pochodzić od Ernsta Didringa ${ }^{61}$, sekretarza Szwedzkiego Czerwonego

${ }^{57}$ M. SMOLEŃ, op.cit., s. 245, przyp. 86.

${ }^{58}$ Stanisław Wiткоwsкi, Polska akcja charytatywna w Skandynawii podczas I wojny światowej. Przyczynek do biografii błogosławionej siostry Urszuli Ledóchowskiej, Chrześcijanin w Świecie, R. 18: 1986, nr 5 (152), s. 46-56.

${ }^{59}$ Pismo Komitetu Generalnego w Vevey do konsula Szwajcarii w Sztokholmie w sprawie pomocy żywnościowej dla Polski, Vevey, 23 IX 1915, Riksarkivet, Stockholm, Röda Korset, Hjälpkommittén för krigsfångar, vol. 327; List A. Osuchowskiego do J. Ledóchowskiej, Vevey, 13 I 1916, AGUSJK w Pniewach. Nils E. Frykholm (18 VI 1863 - 3 II 1918) pełnił funkcję honorowego konsula Szwajcarii w Szwecji od 29 VIII 1910 r. do swojej śmierci.

${ }^{60}$ Gazeta Polska, 4/17 XII 1915, nr 42, s. 2.

${ }^{61}$ Ernst Didring (1868-1931) - szwedzki pisarz i działacz społeczny. W latach 1915-1920 działał w Szwedzkim Czerwonym Krzyżu jako sekretarz tej organizacji. W tym samym czasie pełnił także funkcję prezesa Komitetu Pomocy dla Jeńców Wojennych. Dwukrotnie był 
Krzyża (Svenska Röda Korset), będącego jednocześnie prezesem Komitetu Pomocy dla Jeńców Wojennych (Hjälpkommittén för krigsfångar), i dwóch wybitnych przedstawicieli szwedzkiej inteligencji: dyrektora Muzeum Narodowego w Sztokholmie, profesora archeologii Oskara Monteliusa i doktora medycyny Antona Nyströma. W tym czasie O. Montelius był prezesem powołanego 1 VI 1915 r., z inicjatywy matki U. Ledóchowskiej, Szwedzkiego Komitetu Pomocy dla Polski (Svenska Hjälpkommittén för Polen) nazywanego także Komitetem dla Ofiar Wojny w Polsce, który działał jako filia Komitetu Veveyskiego ${ }^{62}$.

Jak wynika z powyższych rozważań, należy przyjąć za bardzo prawdopodobne, że pomysł utworzenia samodzielnej polskiej placówki o charakterze pomocowym, nazwanej przez J. Everta na łamach „Gazety Polskiej” „Komitetem Polskim", pojawił się w pierwszej kolejności w kręgu osób narodowości szwedzkiej, współpracujących wcześniej z matką U. Ledóchowską, i był związany z nadziejami oparcia tej inicjatywy na szwedzkich instytucjach charytatywnych. Głównym zadaniem tej organizacji miało być dostarczanie żywności dla głodujących mieszkańców Królestwa.

Charakter tego przedsięwzięcia zdaje się potwierdzać publikacja, która pojawiła się na łamach „Dziennika Poznańskiego” 26 I 1916 r., a dwa dni później została przedrukowana w wydaniu popołudniowym przez krakowski „Głos Narodu"63. Redakcja poznańskiego pisma, powołując się na piotrogrodzkie „Биржевые Ведомости” („Birżewyje Wiedomosti”) informowała czytelników, że kwestia dostarczenia artykułów żywnościowych na teren Królestwa nabiera coraz bardziej - jak to sformułowano - „ostrego charakteru”. Jednocześnie podnoszono, co dla naszych rozważań w tym właśnie momencie jest szczególnie istotne, że „w listopadzie w Sztokholmie zawiązał się komitet polski niesienia pomocy mieszkańcom Królestwa w drodze wywozu artykułów spożywczych ze Skandynawii”"64, po czym redakcja - idąc za rosyjskim dziennikiem - stwierdzała, że państwa Ententy zgodziły się na warunkowe dostawy żywności na tereny okupowane przez mocarstwa centralne. Warunkiem tej zgody było zobowiązanie rządu niemieckiego, w postaci oświadczenia kanclerza złożonego na ręce ambasadora Hiszpanii w Berlinie, że z zasobów tych

wybierany prezesem Związku Pisarzy Szwedzkich. Funkcję tę sprawował w latach 1915-1920 i 1923-1929. W tekście opublikowanym przez "Gazetę Polską” błędnie podano jego imię i nazwisko. Jest „Wilhelma Dütringa”, a powinno być „Ernsta Didringa”. Zob. Gazeta Polska, 4/17 XII 1915, nr 42, s. 2; Dziennik Petrogradzki, 22 XII 1915, nr 1656, s. 2.

${ }^{62}$ Sprawozdanie hrabiny Ledóchowskiej skopiowane w delegacji dnia 18 VII 1916 r., ANK, NKN, sygn. 50, k. 36.

${ }^{63}$ Wywóz artykułów spożywczych ze Skandynawii do Polski, Dziennik Poznański, 26 I 1916, nr 20, s. 3; O wyżywieniu Królestwa, Głos Narodu, 28 I 1916, nr 49, s. 1.

${ }^{64}$ Dziennik Poznański, 26 I 1916, nr 20, s. 3. 
nie będą korzystały wojska niemieckie. Jednak w chwili obecnej - pisano dalej - wśród państw czwórporozumienia pojawiły się obawy, czy rząd niemiecki, zobowiązany do zaopatrzenia w żywność ludności na obszarach okupowanych, nie wykorzysta tych produktów na częściowe lub całościowe potrzeby armii. W tej sytuacji, jak informował „Dziennik Poznański”, „powstała kwestia rozpatrzenia pozwolenia, które dano komitetowi polskiemu w Sztokholmie"65. Jeśli chodzi o datację powołania tej nowej struktury organizacyjnej, zresztą bardzo mało precyzyjną, to ze względu na źródło, z którego czerpie „Dziennik Poznański” tę informację, jest bardzo prawdopodobne, że jest ona podana według kalendarza juliańskiego. Zatem termin „zawiązania” owego „komitetu polskiego w Sztokholmie”, biorąc pod uwagę kalendarz gregoriański, może dotyczyć pierwszej dekady grudnia $1915 \mathrm{r}$.

Obecny w tym właśnie czasie w Sztokholmie J. Evert bacznie przyglądał się tym staraniom. Najprawdopodobniej zdawał sobie sprawę z ograniczonych możliwości tej inicjatywy. Główną barierę widział w braku środków finansowych. Po powrocie do Moskwy na łamach „Gazety Polskiej” podkreślał, że tylko wsparcie materialne tej akcji przez wszystkich Polaków, bez względu na to, w jakim kraju obecnie przebywają, może przynieść większe rezultaty. Wskazywał na Polonię rosyjską i wychodźców z Królestwa przebywających w Rosji jako na tę grupę, która przede wszystkim powinna wesprzeć tę inicjatywę ${ }^{66}$.

W czasie pobytu w Sztokholmie J. Evert interesował się także działalnością tzw. Oddziału Polskiego, istniejącego przy Rosyjskim Komitecie Pomocy w Sztokholmie, zwanym potocznie Komitetem Rosyjskim ${ }^{67}$. Zanim przejdziemy do informacji o tej placówce pomocowej, które przekazał czytelnikom „Gazety Polskiej” wiceprezes moskiewskiego Komitetu Polskiego, przyjrzyjmy się bliżej Komitetowi Rosyjskiemu, przy którym Oddział ten ustanowiono.

Rosyjski Komitet Pomocy w Sztokholmie był organizacją charytatywną powołaną z inicjatywy ambasadora Rosji w Szwecji Anatolija Wasiljewicza Niekludowa. Powstał w wyniku nagłej potrzeby, z jaką w pierwszych dniach po wybuchu wojny spotkało się przedstawicielstwo dyplomatyczne Rosji w stolicy Szwecji. Wybuch wojny zaskoczył na terytorium Niemiec licznych poddanych Mikołaja II, głównie narodowości żydowskiej, którzy przebywali tam w znanych uzdrowiskach. Aby uniknąć internowania, społeczność ta starała się jak najszybciej opuścić terytorium Niemiec i znaleźć się w niezagrożonym miejscu. Takim obszarem, z którego w sposób bezpieczny można było dotrzeć do swoich miejsc zamieszkania w Rosji, była Szwecja. Toteż od 2 VIII 1914 r. uchodźcy przez Sassnitz, Trelleborg, Malmö zaczęli licznie przybywać do Sztokholmu.

\footnotetext{
${ }^{65}$ Ibid.

${ }^{66}$ Gazeta Polska, 4/17 XII 1915, nr 42, s. 2.

${ }^{67}$ Ibid.
} 
W krótkim czasie duża liczba napływających z Niemiec przybyszów, którzy potrzebowali pomocy, sparaliżowała pracę rosyjskiego przedstawicielstwa dyplomatycznego. Poselstwo i rosyjski konsulat generalny w Sztokholmie nie były w stanie poradzić sobie z oczekiwaniami i potrzebami uchodźców. Stan liczebny personelu zatrudnionego w obu tych instytucjach okazał się daleko niewystarczający, aby sprostać zadaniom, przed jakimi one stanęły w tej wyjątkowej chwili. Brak środków finansowych pogłębiał jeszcze bardziej i tak już trudną sytuację. Dzięki pożyczce 50000 koron udzielonej przez Emmanuela $\mathrm{Nobla}^{68}$, poddanego cara Mikołaja II, prezesa największego w Europie koncernu naftowego „Branobel”, eksploatującego złoża ropy wokół Baku, a także pomocy finansowej i organizacyjnej rządu szwedzkiego udało się po ok. dwóch tygodniach na tyle opanować sytuację, że konsulat i poselstwo mogły w miarę normalnie wykonywać swoje czynności ${ }^{69}$.

W czasie tej trudnej sytuacji, tak dla samych uchodźców, jak i przedstawicielstwa rosyjskiego, w Poselstwie narodził się pomysł, aby przyjąć do pomocy na zasadach wolontariatu kilka osób spośród rosyjskich uchodźców przebywających w Sztokholmie. Osoby te miały pracować charytatywnie na rzecz potrzebujących rodaków. Całe to przedsięwzięcie spotkało się z pełną akceptacją A. Niekludowa. Wyrazem tego poparcia było objęcie patronatu nad Komitetem przez żonę i wezwaną z Paryża do Sztokholmu siostrę ambasadora. Włączyło się w tę działalność także duchowieństwo Kościoła prawosławnego w Sztokholmie. W krótkim czasie dzięki staraniom samego A. Niekludowa,

${ }^{68}$ Emanuel Nobel urodził się 23 VI 1859 r. w Petersburgu w rodzinie fabrykantów szwedzkich osiadłych w Cesarstwie Rosyjskim od 1837 r. na terenie Finlandii. W 1842 r. dziadek Emanuela, Immanuel Nobel przeniósł się do Petersburga, gdzie otworzył warsztat mechaniczny, dostarczający uzbrojenie dla armii rosyjskiej. W dniu 25 V/6 VI 1879 r. w Baku została zawiązana jedna z największych firm naftowych w tym czasie Towarzystwo Produkcji Ropy Naftowej Braci Nobel „Branobel” (Товарищество Нефтяного Производства Братьев Нобель „Бранобель”) z kapitałem założycielskim w wysokości $3 \mathrm{mln}$ rubli. Założycielami byli trzej bracia: Ludwik, Robert i Alfred Noblowie oraz ich przyjaciel, pułkownik artylerii gwardii, następnie generał i baron Piotr Aleksandrowicz Bilderling (1844-1901). W 1888 r. po śmierci ojca Ludwika Emanuel Nobel, mając 29 lat, stanął na czele koncernu naftowego „Branobel”. W tym samym roku otrzymał z rąk cara Aleksandra III w czasie wizyty rodziny monarszej w Baku poddaństwo rosyjskie i tytuł barona. Po wybuchu rewolucji bolszewickiej w Rosji w wyniku dekretów o nacjonalizacji dotychczasowe posiadłości Noblów zostały przejęte w 1920 r. przez państwo rosyjskie. Po ucieczce z Rosji Emanuel Nobel 26 XI 1918 r. dotarł do Berlina. Po powrocie do Szwecji pod koniec 1918 r. zrzekł się obywatelstwa rosyjskiego. Zmarł 31 V 1932 r. w Sztokholmie. Zob. Eli Hecкscher, Emanuel Nobel, Kungliga Svenska Vetenskapsakademiens årsbok, 1933, s. 294-304.

${ }^{69}$ Anatoly Nekludoff, Diplomatic reminiscences before and during the world war, 19111917, London 1920, s. 312-315, 358-360. Szwedzki przekład jego wspomnień: Anatoly NeKLUDOFF, En diplomats minnen från tiden före och under världskriget 1911-1917, Stockholm 1921. 
jak i jego współpracowników, charytatywna działalność Komitetu Rosyjskiego stała się znana nie tylko w stolicy Szwecji, lecz także w samej Rosji i innych krajach europejskich. W miarę upływu czasu, gdy zmniejszyła się liczba napływających uchodźców, Komitet począł podejmować się nowych zadań. Objęto opieką oficerów i żołnierzy, poddanych cara Mikołaja II, przebywających w jenieckich obozach. W działaniach tych pomagała ambasada Królestwa Hiszpanii w Sztokholmie, ponieważ rząd w Madrycie reprezentował interesy Rosji wobec Niemiec i Austro-Węgier. Przedstawicielstwa dyplomatyczne tego państwa w Berlinie i Wiedniu pośredniczyły w wymianie korespondencji między jeńcami a ich rodzinami, w przesyłaniu pieniędzy i dostarczaniu paczek ${ }^{70}$.

Nie znamy dokładnej daty utworzenia Oddziału Polskiego przy Rosyjskim Komitecie Pomocy. Jak wynika z relacji J. Everta na łamach „Gazety Polskiej”, Oddział ten już istniał na przełomie listopada i grudnia $1915 \mathrm{r} .{ }^{71}$ Sprawa znaczenia tej placówki dla niesienia pomocy ludności Królestwa była podnoszona na naradzie władz Centralnego Komitetu Obywatelskiego w Piotrogrodzie 8/21 XII 1915 r. $^{72}$ Z kolei na stronach „Kuriera Poznańskiego” z 9 IV 1916 r. czytamy, że Oddział Polski przy Komitecie Rosyjskim został powołany „niedawno temu"73. Wnioskując z powyższych informacji, należy przypuszczać, że Oddział Polski przy Komitecie Rosyjskim utworzono już po wkroczeniu wojsk państw centralnych do Królestwa w sierpniu 1915 r. Zajęcie przez Niemcy i Austro-Węgry zachodnich guberni Rosji spowodowało odcięcie polskich wychodźców, szeroko rozsianych po całym rosyjskim imperium, od członków ich rodzin pozostałych na ziemiach Królestwa ${ }^{74}$. Stąd zaistniała potrzeba powołania placówki, która w założeniu miała nieść pomoc w nawiązaniu kontaktu między obiema społecznościami. Najbardziej prawdopodobnym terminem ustanowienia Oddziału Polskiego przy Komitecie Rosyjskim wydaje się zatem październik lub listopad $1915 \mathrm{r}$.

Nie wiadomo, kto był inicjatorem powołania tej placówki. Czy inicjatywa wyszła z kręgu współpracowników A. Niekludowa, od niego samego czy też od przywołanego przez J. Everta w wywiadzie na łamach „Gazety Polskiej”

${ }^{70}$ A. Nekludoff, Diplomatic reminiscences, s. 312-315, 358-360; Gazeta Polska, 4/17 XII 1915, nr 42, s. 2.

${ }^{71}$ Gazeta Polska, 4/17 XII 1915, nr 42, s. 2.

${ }^{72}$ Protokół narady członków C.K.O. z dnia 8/21 XII 1915 r., AAN, Centralny Komitet Obywatelski w Piotrogrodzie (dalej cyt. CKO w Piotrogrodzie), sygn. 1, k. 49.

${ }^{73}$ Z działalności Komitetu polskiego w Sztokholmie, Kurier Poznański, 9 IV 1916, nr 83, s. 3.

${ }^{74}$ Mariusz Korzeniowski, Marek Mądzik, Dariusz Tarasıuk, Tułaczy los. Uchodźcy polscy $w$ imperium rosyjskim $w$ latach pierwszej wojny światowej, Lublin 2007, s. 32-36. Zob. zestawienie rozmieszczenia uchodźców z Królestwa Polskiego w imperium rosyjskim w latach 1915-1917 w: ibid., s. 32-36, tab. 2. 
jako kierownika Oddziału Polskiego, ks. Floriana Markowskiego ${ }^{75}$. Przekaz redakcji „Gazety Polskiej” w tej kwestii nie jest ani zbyt czytelny, ani jednoznaczny. Dziennik, czerpiąc wiedzę od J. Everta, pisał o tej kwestii w sposób następujący: „Wszedł on [ks. Markowski - S.W.] w stosunki z Komitetem Rosyjskim, pozostającym pod protektoratem żony i siostry ambasadora A. Niekludowa i został kierownikiem oddziału polskiego tego Komitetu"76.

A może, jak zdaje się sugerować A. N. Uggla, wskazując na powiązania tej placówki z Narodową Demokracją, ślad prowadzi w kierunku Centralnego Komitetu Obywatelskiego (CKO)? Jak czytamy w protokole narady członków CKO z 8/21 XII 1915 r., w gronie działaczy tej organizacji pojawił się projekt

${ }^{75}$ Ks. Florian Markowski urodził się 30 XII 1887 r. w Wilnie. W czasie pierwszej wojny światowej przebywał w Szwecji. Mieszkał w położonej $15 \mathrm{~km}$ od Sztokholmu miejscowości letniskowej Djursholm (obecnie dzielnica szwedzkiej stolicy). Według zachowanej karty rejestru wizy pochodzącej z Biura Policji Państwowej (Statens polisbyrå) wizę szwedzką otrzymał 14 XI $1918 \mathrm{r}$. Była ona przez władze szwedzkie przedłużana co kilka miesięcy. Ostatni wpis w karcie rejestru nosi datę "1.6.[1921] - 30.11.[19]21”. Według zachowanych kart, które hotele wysyłały do Statens polisbyrå (ten system kontroli cudzoziemców - jak wspomnieliśmy - wprowadzono w lutym 1916 r.), wiemy o jego pobytach w Szwecji z lat 1919-1920. Miejsca przez niego odwiedzane świadczą o tym, że były to najpewniej podróże o charakterze duszpasterskim. W dniach 26-27 XI 1919 r. odwiedził Norrköping, gdzie znajdowała się jedna z pięciu katolickich stacji misyjnych. W trzeciej dekadzie grudnia 1920 r. podróżował po południowo-zachodniej Szwecji. Najpierw pojawił się w Oskarström (w latach 1914-1920 miało przebywać tam ok. 300 osób pochodzenia polskiego, z których większość pracowała w fabryce przerabiającej jutę). Z Oskarström wyjechał 20 grudnia i po przebyciu ok. $100 \mathrm{~km}$ dotarł do Hälsingborgu (zachowano pisownię nazwy tego miasta z 1920 r.). W dniu następnym udał się do Landskrony, gdzie gościł od 21 do 23 grudnia (na północny wschód od tego portowego miasta, w folwarkach akcyjnego towarzystwa cukrowni w Söbyholm, pracowali polscy robotnicy rolni). W dniu 23 grudnia przybył do Malmö, gdzie znajdowała się jedna z pięciu katolickich stacji misyjnych w Szwecji. Tam najprawdopodobniej spędził święta Bożego Narodzenia. Następnie udał się do Kristianstad (w odległości ok. $25 \mathrm{~km}$ od tego miasta znajdowała się miejscowość Bromölla, gdzie w kopalniach i fabryce kaolinu pracowała dość liczna grupa Polaków). Z Kristianstad wyjechał 29 grudnia i po pokonaniu ok. $350 \mathrm{~km}$ dotarł do Linköping. W dniu 30 grudnia udał się do Gamleby. Odległość z Gamleby do majątku Kulla, gdzie mieszkali Józefa z Pomianów i Gustaw Armfeltowie, wynosiła ok. 20 km. Jest bardzo prawdopodobne, że ks. Markowski przybył do Kulla i spędził tam Nowy Rok. Brak następnych kart hotelowych w Statens polisbyrå wskazuje, że był to ostatni etap jego podróży, po którym powrócił do Sztokholmu. Riksarkivet, Stockholm, Statens polisbyrå, vol. E6:89 (1919), E6:118 (1920). Zob. karty dotyczące ks. F. Markowskiego wysyłane przez hotele do Statens polisbyrå w: Karta rejestru wizy ks. F. Markowskiego, Riksarkivet, Stockholm, Statens utlänningskommission huvudarkivet, vol. D1 A:58. Zob. też Józef SzymaŃSKI, Próby organizowania opieki duszpasterskiej nad wychodźstwem polskim w Szwecji do II wojny światowej, Summarium, nr 36 (56): 2007, s. 18; Marian Walczak, Polska emigracja zarobkowa i polityczna w Szwecji w dziewiętnastym i dwudziestym wieku, Jarocin 1993, s. 48; idem, Polacy w Szwecji w latach 1900-1939, [in:] Różnorodność i pluralizm. Idee naszego czasu?, red. Włodzimierz Heller, Mariusz ChoŁody (Studia Pedagogiczno-Artystyczne, t. 5), Poznań-Kalisz 2005, s. 146.

${ }^{76}$ Gazeta Polska, 4/17 XII 1915, nr 42, s. 2. 
utworzenia w miejsce Oddziału Polskiego „osobnego przedstawicielstwa polskiego w Szwecji”77. Powyższa informacja mogłaby wskazywać na CKO jako tę organizację, która miała możliwości decyzyjne wobec Oddziału Polskiego przy Komitecie Rosyjskim. Nie ma co do tego jednak pełnej jasności, gdyż dalsza relacja J. Everta w „Gazecie Polskiej” zdaje się przeczyć tym przypuszczeniom. Wiceprezes Komitetu Polskiego w Moskwie wskazywał bowiem na znaczenie i korzyści, jakie Oddział Polski mógł oddać polskiej emigracji w Rosji. Podnosił też jego znaczenie dla komunikacji pocztowej z Królestwem. Twierdził, że bez wsparcia pieniężnego ze strony polskiej emigracji trudno będzie utrzymać działalność tej placówki ${ }^{78}$. Takie publiczne postawienie sprawy przez członka Wydziału Wykonawczego Rady Zjazdów sugeruje, że J. Evert właśnie w ten sposób starał się wywierać wpływ na gremia kierownicze tej organizacji w Moskwie w celu zainteresowania jej tą inicjatywą. Postulował podjęcie starań, które pozwoliłyby przejąć na swój budżet tę „polską” placówkę charytatywną.

Jak wynika z relacji J. Everta, placówka ta przede wszystkim stawiała sobie za cel pośredniczenie w przesyłaniu korespondencji między Polakami w Rosji a ich bliskimi przebywającymi na okupowanych przez państwa centralne ziemiach Królestwa. Wszyscy, którzy chcieli skorzystać z usług Oddziału Polskiego przy Komitecie Rosyjskim w Sztokholmie, powinni byli adresować swoje listy na adres: „Ryska Kommitte et Stockholm, Hotel Continental”, dopisując na kopercie „Oddział Polski” lub „ks. Markowski”79.

Według relacji „Gazety Polskiej” korespondencja nadsyłana przez polskich wychodźców w Rosji do Oddziału Polskiego przy Komitecie Rosyjskim w Sztokholmie była, zgodnie $\mathrm{z}$ wymogami władz niemieckich, tłumaczona z języka polskiego lub rosyjskiego na język niemiecki, a następnie wysyłana do Królestwa. Tą samą drogą - jak pisano - można było przesyłać także pieniądze. Wymagało to jednak załączenia dodatkowych opłat. Funkcję tę spełniały włożone do koperty rosyjskie marki pocztowe o wartości 30 kopiejek $^{80}$.

W czasie pobytu w Sztokholmie J. Evert zapewne odbywał spotkania i prowadził rozmowy z przedstawicielami polskiej kolonii w tym mieście. Prawdo-

${ }^{77}$ Protokół narady członków C.K.O. dnia 8/21 XII 1915 r., AAN, CKO w Piotrogrodzie, sygn. 1, k. 69.

${ }^{78}$ Gazeta Polska, 4/17 XII 1915, nr 42, s. 2.

${ }^{79}$ Ibid.

${ }^{80}$ Ibid. Redakcja „Echa Polskiego” na pytanie jednej z czytelniczek, czy pismo utrzymuje korespondencję z Królestwem, odpowiedziała, powołując się na "Gazetę Polską", że ta „podaje nowy sposób korespondowania z Królestwem. List krótki z wiadomościami tylko rodzinnemi, pisany po polsku p.[od] adr.[esem] Ryska Comitet Stockholm, Hotel Continental, Oddział Polski, ks. Markowski - tłumaczą w Sztokholmie na język polski [informacja błędna - chodzi o tłum. na język niemiecki - S.W.] i wysyłają pod wskazanym adresem. W list należy włożyć 20-30 kop. w markach rosyjskich"; zob. Odpowiedzi od redakcji, Echo Polskie, 13/26 XII 1915, nr 14, s. 16. 
podobnie spotkał się z także matką U. Ledóchowską, która powróciła w tym właśnie czasie (między 26 a 28 XI 1915 r.) do Djursholm z miesięcznej akcji odczytowej, jaką prowadziła w miastach Szwecji i Danii na rzecz Komitetu Veveyskiego ${ }^{81}$. Piszemy: prawdopodobnie, ponieważ nie dysponujemy żadnym przekazem źródłowym na ten temat. Milczy o tym w swoich wspomnieniach również matka Urszula. Byłoby jednak czymś zupełnie niezrozumiałym, gdyby J. Evert mając taką możliwość, nie nawiązał kontaktu z osobą, która w tym czasie była najbardziej znaną, obok H. Sienkiewicza i I. J. Paderewskiego, postacią w Skandynawii, uosabiającą sprawę polską w szwedzkiej i duńskiej opinii publicznej. Trudno przypuszczać, aby tak doświadczony polityk, jakim bez wątpienia był J. Evert, mógł popełnić taki błąd. Jesteśmy przekonani, że tego nie zrobił. Wynika to także ze wspomnianej wypowiedzi J. Everta dla „Gazety Polskiej”. Opisana tam według jego relacji działalność matki U. Ledóchowskiej na terenie Szwecji, zwłaszcza w Danii, zawiera informacje, które - jak się wydaje - mogła przekazać J. Evertowi jedynie sama zainteresowana ${ }^{82}$. Także treść listu J. Zdziechowskiego, datowanego w Moskwie na 16/29 I 1916 r., wysłanego w imieniu Rady Zjazdów na ręce matki U. Ledóchowskiej, wskazuje, że do takiego spotkania najprawdopodobniej doszło. W piśmie podpisanym przez J. Zdziechowskiego czytamy: „Od p. Józefa Ewerta dowiedzieliśmy się o inicjatywie Sz. Pani co do utworzenia przy Szwedzkim Towarzystwie Czerwonego Krzyża Polskiego Oddziału i o tych trudach i staraniach jakie Sz. Pani dla dobra tej instytucji ponosi" 83 .

W tym momencie rodzą się pytania sięgające istoty genezy powołania Komitetu Polskiego w Sztokholmie, które powinniśmy zadać, nim przejdziemy do dalszych rozważań nad działalnością tej organizacji: czy tematem konsultacji J. Everta z przedstawicielami polskiego wychodźstwa w stolicy Szwecji był projekt przywieziony z Moskwy, który powstał w kręgu A. Lednickiego, jak infor-

${ }^{81}$ Matka U. Ledóchowska rozpoczęła objazd Szwecji i Danii odczytem w Sztokholmie 27 X 1915 r., 2 listopada była w Uppsali, 5 listopada w Falköping, 9 listopada w Göteborgu, 12 listopada w Malmö i 13 listopada w Lund i Helsinborg, 15 listopada była już w Kopenhadze, gdzie 18 dnia tegoż miesiąca odbył się jej pierwszy odczyt, a sześć dni później - 24 listopada następny. Dzień później przyjmowała wpłaty od ofiarodawców w kopenhaskim hotelu. Dnia 29 listopada była już z powrotem w Djursholm. Taką datę zawiera list skierowany do Georga Brandesa w Kopenhadze. Z powyższego wynika, że powróciła do miejsca swojego stałego pobytu między 26 a 28 XI 1915 r. List J. Ledóchowskiej do A. Osuchowskiego w Vevey [brak daty], AGUSJK w Pniewach. List ten spisany został zapewne między 28 i 31 X 1915 r. List J. Ledóchowskiej do G. Brandesa, Kopenhaga, 16 XI 1915, AGUSJK w Pniewach; List J. Ledóchowskiej do G. Brandesa, Djursholm, 29 XI 1915, AGUSJK w Pniewach; Sprawozdanie hrabiny Ledóchowskiej, AGUSJK w Pniewach, k. 36-37.

${ }^{82}$ Gazeta Polska, 4/17 XII 1915, nr 42, s. 2; Dziennik Petrogradzki, 9/22 XII 1915, nr 1656, s. 2.

${ }^{83}$ Pismo wiceprezesa Rady Zjazdów J.Zdziechowskiego do J.Ledóchowskiej, AGUSJK w Pniewach. 
muje matka U. Ledóchowska, czy też wprost przeciwnie, dyskutowano o pomyśle, który - jak twierdzi A. de Pomian - narodził się w środowisku polskich wychodźców, a następnie zaakceptował go Wydział Wykonawczy Rady Zjazdów? A może koncepcja powołania polskiej organizacji charytatywnej w Sztokholmie była owocem wspólnym, powstałym w wyniku dyskusji J. Everta i jego sztokholmskich rozmówców, po czym została zawieziona do Moskwy, gdzie zapoznał się z nią i ją zaakceptował Wydział Wykonawczy Rady Zjazdów?

Nie znajdujemy jednoznacznej odpowiedzi na tak postawione pytania. Wiadomo jednak z całą pewnością, że w czasie pobytu J. Everta w Sztokholmie była omawiana z przedstawicielami polskiego wychodźstwa w Szwecji kwestia powołania organizacji o charakterze pomocowym. Wiadomo także, że wysłannik moskiewskiego Komitetu Polskiego obiecał swoim rozmówcom, że organizacje wychodźcze w Rosji będą finansowały tę nową charytatywną strukturę. Świadczy o tym telegram wysłany przez Centralny Komitet Obywatelski w Piotrogrodzie. Telegram ten, podpisany przez Seweryna Wachowskiego, jest niedatowany, dlatego trudno go umiejscowić w szeregu następującym po sobie wydarzeń. Nagłówek, jaki nosi: „do Hajdukiewicza-Pomiana, przewodniczącego Komitetu Polskiego w Sztokholmie”, pozwala jednak przypuszczać, że wysłano go w drugiej połowie lutego lub pierwszej połowie marca 1916 r., więc już po powrocie wysłannika Wydziału Wykonawczego Rady Zjazdów S. Wachowskiego z misji do stolicy Szwecji. Podróż ta odbyła się w pierwszej dekadzie lutego 1916 r. W telegramie czytamy, co następuje: „Attend argent promis par ewert son sejour ici. Wachowski" ${ }^{\text {. }}$.

Treść telegramu jednoznacznie utwierdza nas w przekonaniu, że J. Evert w czasie pobytu w Sztokholmie nie tylko prowadził rozmowy z przedstawicielami polskiego wychodźstwa w stolicy Szwecji dotyczące powołania polskiej organizacji charytatywnej, lecz także - przez złożenie oferty finansowania tej placówki - sam stał się jej inspiratorem. Nie wiemy, czy J. Evert już w tym momencie oferował swoim rozmówcom jakąś konkretną kwotę, która miała zapewnić Komitetowi funkcjonowanie, czy pozostawiono tę sprawę do decyzji polskich instytucji opiekuńczych w Rosji. Właśnie ta decyzja podjęta przez polskie organizacje pomocowe w Rosji, jak się potem miało okazać, comiesięcznej stałej kwoty pieniężnej była głównym argumentem do podjęcia tej inicjatywy przez polskich uchodźców w stolicy Szwecji.

Złożenie przez J. Everta oferty finansowej wobec przedstawicieli polskiej emigracji w Szwecji nie pociągało za sobą automatycznego powołania nowej

84 „Czekać na pieniądze obiecane przez Ewerta. Wachowski” [trans. i tłum. - S.W.]; Telegram Centralnego Komitetu Obywatelskiego do Hajdukiewicza-Pomiana, przewodniczącego Komitetu Polskiego w Sztokholmie podpisany przez S. Wachowskiego [odpis bez daty], AAN, CKO w Piotrogrodzie, sygn. 41, k. 68. 
organizacji charytatywnej. Do wykonania tej pracy potrzebni byli ludzie, którzy działając w specyficznych szwedzkich warunkach, będą potrafili doprowadzić do zjednoczenia wokół głoszonego programu znaczącej części osób spośród przebywającego w tym kraju polskiego wychodźstwa. Zatem sam akt powołania nowej struktury organizacyjnej, której zadaniem miała być praca na rzecz polskiego wychodźstwa w Szwecji, spoczął na barkach sztokholmskiej Polonii. Potwierdzeniem tego wysiłku zdaje się cytowany już fragment $\mathrm{z}$ raportu A. de Pomiana z 24 I 1919 r., adresowany do W. Sobańskiego ${ }^{85}$.

Podsumowując, należy stwierdzić, że Komitet Polski działający w latach 1916-1919 w stolicy Szwecji powstał z inicjatywy kolonii polskiej w Rosji i przybyłych tam uchodźców z ziem Królestwa w czasie działań wojennych. Powołana tam organizacja polonijna pod nazwą Rada Zjazdów Polskiej Organizacji Pomocy Ofiarom Wojny na czele z A. Lednickim, finansowana z budżetów rosyjskich organizacji społecznych i państwowych, podjęła trud stworzenia placówki charytatywnej w stolicy Szwecji, mającej udzielać pomocy Polakom bez względu na ich przynależność państwową. Ekspedycja J. Everta na przełomie listopada i grudnia $1915 \mathrm{r}$. (wg nowego stylu) do Sztokholmu, rozmowy tam przeprowadzone z przebywającymi w stolicy Szwecji emigrantami polskimi urodzonymi już w tym kraju oraz wojennymi przebywającymi tam od kilkunastu miesięcy ostatecznie zaowocowały podjętym przez emisariusza Rady Zjazdów zobowiązaniem finansowania tej nowej placówki. Świadczy o tym przytoczony telegram S. Wachowskiego do prezesa utworzonego dopiero co Komitetu Polskiego A. de Pomiana.

\section{BIBLIOGRAFIA}

Bojarska, Teresa. W imię trzech krzyży. Opowieść o Julii Urszuli Ledóchowskiej i jej zgromadzeniu. Warszawa: Instytut Wydawniczy PAX, 1989.

Czermiński, Marcin. "Misje dla Polaków w Szwecji we wrześniu i październiku r. 1906." Missye Katolickie. Czasopismo Ilustrowane Miesięczne 26/5 (1907): 127-135.

Ćwirko-Godycka, Janina J. Organizacje polonijne w Szwecji i ich działalność. Jonstorp: Wiktoriana Förlag, 1996.

Dzierzbicki, Stanisław. Pamiętnik z lat wojny 1915-1918. Edited by Janusz Pajewski, Danuta Płygawko and Tomasz Jodełka-Burzecki. Warszawa: Państwowy Instytut Wydawniczy, 1983.

Evert-Kappesowa, Halina. “Evert Ludwik Józef (1863-1945).” In Polski słownik biograficzny, vol. 6, 323-324. Kraków: Polska Akademia Umiejętności, 1948.

${ }^{85}$ Raport A. de Pomiana skierowany na ręce hr. W. Sobańskiego, AAN, KNP w Paryżu, sygn. 2031, k. 81. 
Heckscher, Eli. “Emanuel Nobel." Kungliga Svenska Vetenskapsakademiens årsbok (1933): 294-304.

Korzeniowski, Mariusz, Marek Mądzik and Dariusz Tarasiuk. Tułaczy los. Uchodźcy polscy w imperium rosyjskim w latach pierwszej wojny światowej. Lublin: Wydawnictwo UMCS, 2007.

Lam, Stanisław. Życie wśród wielu. Warszawa: Państwowy Instytut Wydawniczy, 1968.

Lednicki, Aleksander. Pamiętnik 1914-1918. Edited by Zbigniew Koziński. Kraków: Biblioteka Jagiellońska, 1994.

Lednicki, Wacław. Pamiętniki, vol. 2. Londyn: B. Świderski, 1967.

Ledóchowska, Józefa. Życie i działalność Julii Urszuli Ledóchowskiej. Poznań: Pallottinum, 1975.

Ledóchowska, Ursule. Histoire de la Congrégation des Ursulines C.J.A. Lyon: Belmont-Tramonet, 1992.

Ledóchowska, Urszula. Byłam tylko pionkiem na szachownicy... Wspomnienia $z$ lat 1886-1924. Częstochowa: Edycja Świętego Pawła, 2007.

Ledóchowska, Urszula. Historia Kongregacji Sióstr Urszulanek Najświętszego Serca Jezusa Konajacego. Edited by Andrzeja Górska, Angelika Jakubiak, Ancilla Kosicka and Józefa Zdybicka. Poznań: Pallotinum, 1987.

Matuszak, Kazimierz. “Polski Komitet Pomocy w Szwecji." In Polacy w Szwecji po II wojnie światowej. Materiały sympozjum, luty 1989, 13-21. Sztokholm: Kongres Polaków w Szwecji, 1992.

Nekludoff, Anatoly. Diplomatic reminiscences before and during the world war, 1911-1917. New York, London: E.P. Dutton and Company, 1920.

Nekludoff, Anatoly. En diplomats minnen frän tiden före och under världskriget 1911-1917. Stockholm: Norstedt, 1921.

Olchowicz, Konrad. Ćwierć wieku z 'Kurierem Warszawskim'. Kraków: Wydawnictwo Literackie, 1974.

Pajewski, Janusz and Aleksandra Kosicka-Pajewska, eds. Pamiętnik księżnej Marii Zdzisławowej Lubomirskiej 1914-1918. Poznań: Wydawnictwo Poznańskie, 1997.

Piber, Andrzej. “Alf de Pomian.” In Polski słownik biograficzny, vol. 27, 381-382. Wrocław: Wydawnictwo Zakładu Narodowego im. Ossolińskich, 1982-1983.

Sibora, Janusz. Dyplomacja polska w I wojnie światowej. Warszawa: Polski Instytut Spraw Międzynarodowych, 2013.

Sibora, Janusz. Narodziny polskiej dyplomacji u progu niepodległości. Warszawa: Wydawnictwo Sejmowe, 1998.

Skręt, Rościsław. "Rabski Władysław (1865-1925)." In Polski słownik biograficzny, vol. 29, 561-564. Wrocław: Wydawnictwo Zakładu Narodowego im. Ossolińskich, 1986.

Smoleń, Mieczysław. “Działalność polityczna Aleksandra Lednickiego w Rosji.” PhD diss., Archiwum Biblioteki Jagiellońskiej, 1979.

Sokolnicki, Michał. Rok czternasty. Londyn: Gryf, 1961.

Sputek, Irena. Polacy w Piotrogrodzie 1914-1917. Warszawa: Państwowe Wydawnictwo Naukowe, 1966.

Staniszewski, Adam. Po dwóch stronach Battyku. Polityczno-gospodarcze stosunki polsko-szwedzkie w latach 1918-1932. Toruń: Wydawnictwo ECE, 2013. 
Szymański, Józef. "Próby organizowania opieki duszpasterskiej nad wychodźstwem polskim w Szwecji do II wojny światowej." Summarium 36 (2007): 135-167.

Uggla, Andrzej N. “Komitet Pomocy w Szwecji 1916-1918." Pamiętnik Literacki 28 (2003): 8-24.

Uggla, Andrzej N. "Rola Alfa de Pomiana-Haydukiewicza w grze o wizerunek Polski w Szwecji po pierwszej wojnie światowej.” In Polska-Szwecja 1919-1999, edited by Jan Szymański, 77-93. Gdańsk: Wydawnictwo Uniwersytetu Gdańskiego, 2000.

Uggla, Andrzej N. "Svensk-polska hjälpkommittén i Sverige 1916-1918." Studia Scandinavica. Zeszyty Naukowe Uniwersytetu Gdańskiego 14 (1996): 101-110.

Walczak, Marian. “Polacy w Szwecji w latach 1900-1939.” In Różnorodność i pluralizm. Idee naszego czasu?, edited by Włodzimierz Heller and Mariusz Chołody, 137-170. Poznań, Kalisz: Uniwersytet im. Adama Mickiewicza, 2005.

Walczak, Marian. Polska emigracja zarobkowa i polityczna w Szwecji w dziewiętnastym i dwudziestym wieku. Jarocin: Państwowy Ośrodek Kształcenia Bibliotekarzy, 1993.

Wasilewski, Zygmunt, ed. Proces Lednickiego. Fragment z dziejów odbudowy Polski 1915-1924. Warszawa: Księgarnia Rolnicza, 1924.

Witkowski, Stanisław. "Polska akcja charytatywna w Skandynawii podczas I wojny światowej." Chrześcijanin w Świecie 18/5 (1986): 46-56.

Witkowski, Stanisław. "Polska placówka prasowa w Kopenhadze w latach 1915-1917." Kwartalnik Historii Prasy Polskiej 31/1 (1992): 103-115.

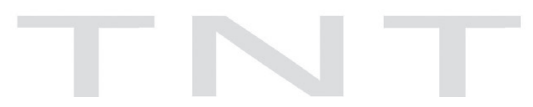

